\title{
Sales of Distressed Residential Property: What Have We Learned from Recent Research?
}

\author{
Jeffrey P. Cohen, Cletus C. Coughlin, and Vincent W. Yao
}

\begin{abstract}
During the housing bust many homeowners found themselves "underwater"- the amount they owed on their mortgages exceeded the value of the associated property-and they either could not or possibly chose not to stay current on their mortgage payments. As a consequence, sales of so-called distressed properties, often after a foreclosure, became commonplace. This spurred numerous research papers on various related issues. The authors' review summarizes the research findings on three topics: the impact of changes in housing prices on foreclosures; the impact of foreclosure on the sales price of the foreclosed house; and the impact of foreclosure on the sales prices of nearby houses. Not surprisingly, declining housing prices are associated with increasing foreclosure rates; however, various other factors, such as a job loss or expected housing prices, can also play an important role. This review highlights various theoretical and econometric issues that have raised doubts about the accuracy of estimated price impacts of foreclosures and led to numerous refinements of the subsequent empirical analysis. Estimates of the own foreclosure discount generally range from near zero to 28 percent, with most estimates greater than 12 percent. Estimates of the discount resulting from spillover effects of nearby foreclosed houses are generally less than 2 percent and diminish rapidly with distance. (JEL R31)
\end{abstract}

Federal Reserve Bank of St. Louis Review, Third Quarter 2016, 98(3), pp. 159-88.

http://dx.doi.org/10.20955/r.2016.159-188

D evelopments in the residential housing market had major impacts on overall U.S. economic activity in the run-up to the Great Recession and its aftermath. ${ }^{1}$ The housing boom was characterized by liberal credit availability, high rates of construction, and rapid price increases that increased the wealth and consumption of many homeowners. However, during the housing bust many homeowners became "underwater"-the amount they owed on their mortgages exceeded the value of the associated property-and they either could not or possibly chose not to stay current on their mortgage payments. As a consequence, sales of so-called distressed properties, often after a foreclosure, became commonplace.

\footnotetext{
Jeffrey P. Cohen is an associate professor of real estate and finance in the School of Business at the University of Connecticut. Cletus C. Coughlin is a senior vice president and chief of staff at the Federal Reserve Bank of St. Louis. Vincent Yao is an associate professor of real estate in the Robinson College of Business at Georgia State University. Jonas Crews provided research assistance.

○ 2016, Federal Reserve Bank of St. Louis. The views expressed in this article are those of the author(s) and do not necessarily reflect the views of the Federal Reserve System, the Board of Governors, or the regional Federal Reserve Banks. Articles may be reprinted, reproduced, published, distributed, displayed, and transmitted in their entirety if copyright notice, author name(s), and full citation are included. Abstracts, synopses, and other derivative works may be made only with prior written permission of the Federal Reserve Bank of St. Louis.
} 


\section{Cohen, Coughlin, Yao}

Distressed sales can be viewed as an anomaly in most housing markets. They are not typical arm's-length transactions and generally account for a small subset of housing transactions. However, the number and relative share of distressed sales rose substantially during the housing bust. Not surprisingly, this spurred much interest in various aspects of these sales.

Generally speaking, distressed property is sold in one of the following ways: (i) As an alternative to foreclosure, the lender allows a short sale (i.e., the proceeds of the sale are less than the amount owed on the property) by the borrower. (ii) The lender initiates the foreclosure process under a notice of default and the property is sold during the process by the borrower. Or (iii) the lender forecloses on the property, takes title, and then sells the property as real estate owned (REO). ${ }^{2}$ As discussed in Clauretie and Daneshvary (2011), these alternatives present lenders with trade-offs involving various costs, such as the price discount and marketing time.

Concerning the third option, there are two methods for foreclosing on a property: judicial and nonjudicial. ${ }^{3}$ When no power of sale clause is required in the state, the mortgage holder must file a lawsuit and obtain court approval to foreclose. Once granted, the property can be sold. A nonjudicial foreclosure is allowed when a power of sale clause is required in the state. The property owner is given a period to become current on his or her payment status and another period before the foreclosed property goes on the market. As a result, the time required to implement judicial foreclosures tends to be longer than for nonjudicial foreclosures. ${ }^{4}$

The bursting of the housing bubble led to numerous research articles examining various empirical and theoretical issues relating to the sale of distressed residential property. Given the accumulation of research, now is an appropriate time to take stock of what we have learned. ${ }^{5}$ Our review cannot be characterized as exhaustive, as we focus on three topics: the impact of changes in housing prices on foreclosures; the impact of foreclosure on the sales price of the foreclosed house; and the impact of foreclosure on the sales prices of nearby houses. Prior to examining the research on these topics, we provide some background information on the housing market and the basic issues that we review.

\section{AN OVERVIEW OF THE RESIDENTIAL HOUSING MARKET OVER THE PAST 20 YEARS}

To provide some context for our review, we begin by summarizing some basic information about the housing market over recent years. This information is organized into five categories-prices, foreclosures, homeownership, construction, and sales.

\section{The Rise and Fall in House Prices}

Housing prices began to accelerate in the late 1990s. According to the CoreLogic National Home Price Index, housing prices peaked in April 2006. ${ }^{6}$ The level of this index, including and excluding distressed sales, is shown in Figure 1, while year-over-year changes are shown in Figure 2. Focusing on the measure of the index including distressed sales (i.e., the CoreLogic National Home Price Index in the figures), Figure 1 highlights the rapid run-up in housing 


\section{Figure 1}

\section{Home Price Indexes}

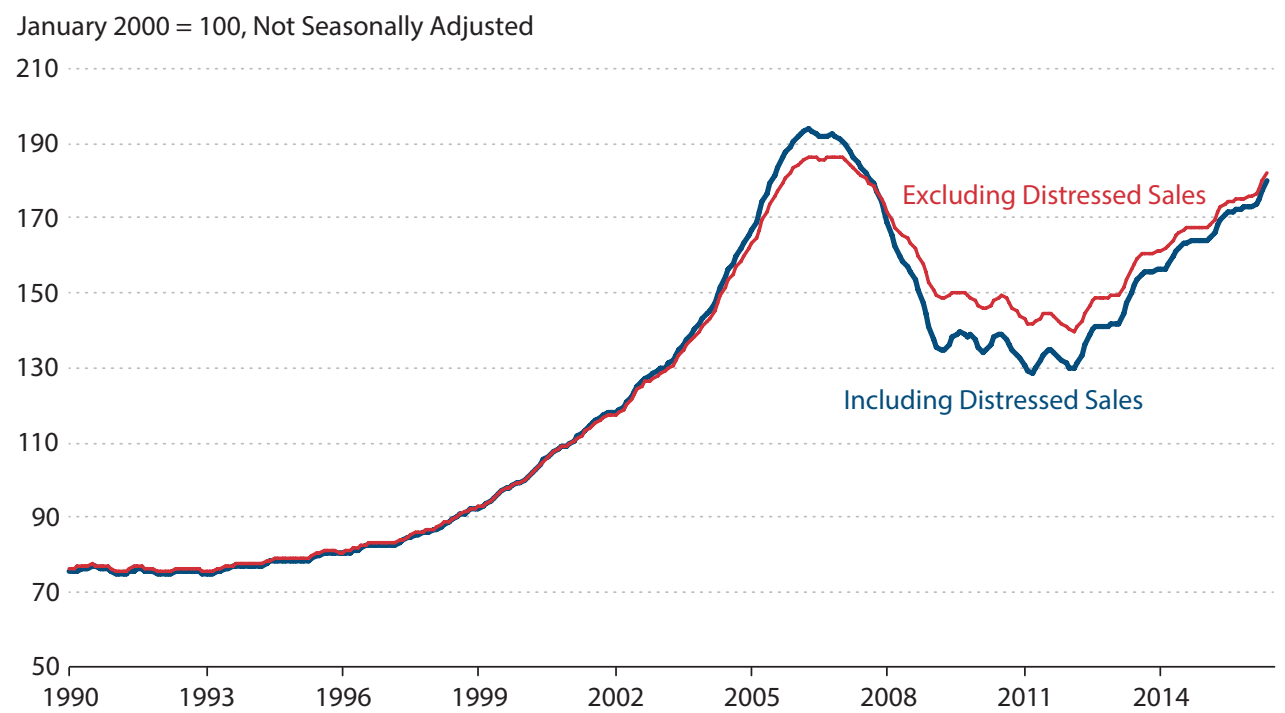

SOURCE: CoreLogic/Haver Analytics.

\section{Figure 2}

\section{Home Price Growth}

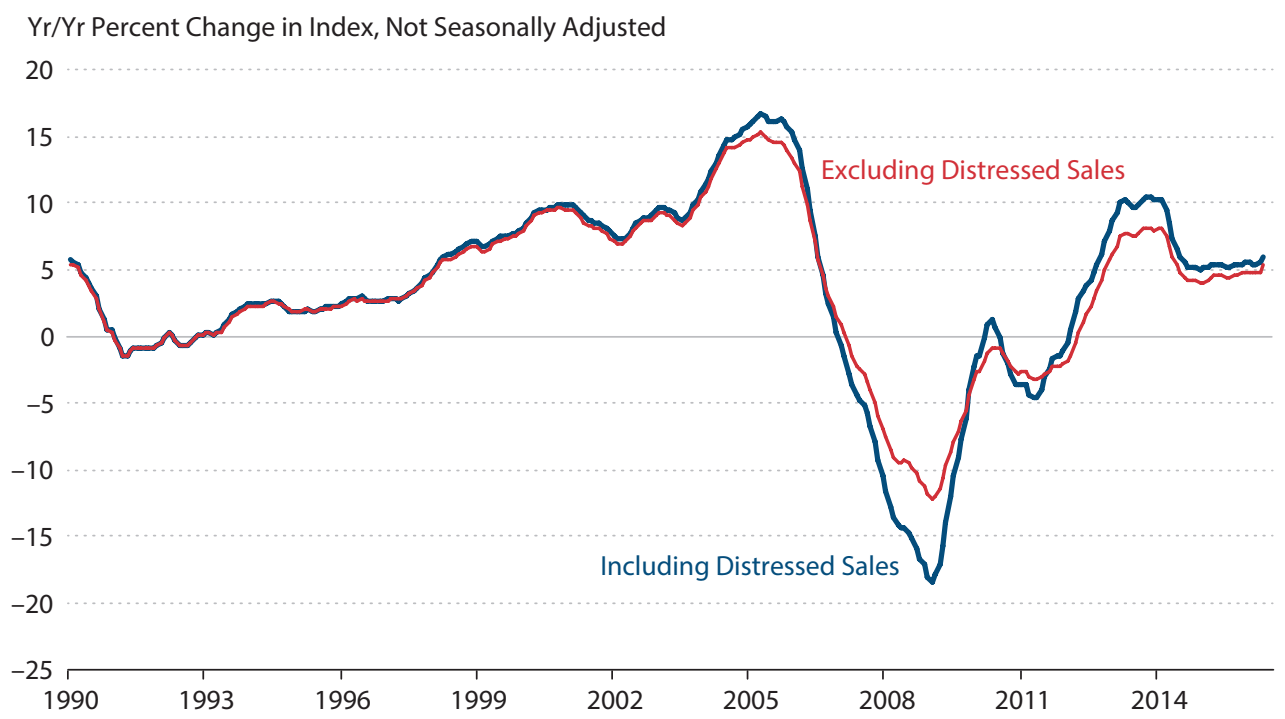

SOURCE: CoreLogic/Haver Analytics. 


\section{Cohen, Coughlin, Yao}

prices. Figure 2 shows that during this run-up, year-over-year increases consistently exceeded 5 percent from January 1998 and reached as high as 16.6 percent in April 2005, much faster than the rate of increase in consumer prices. ${ }^{7}$

Most agree that housing prices in the mid-2000s reflected a bubble; however, there is much disagreement as to the causes of the bubble. Common explanations include the following: excess credit supply, excessively accommodative monetary policy, a global savings glut, government policies encouraging homeownership, irrationally optimistic beliefs about future housing price appreciation, inelastic housing supply, and an excess of mispriced mortgage finance. ${ }^{8}$ Ultimately, the bubble burst. Beginning in April 2006, housing prices declined until reaching a trough in March 2011. During this period housing prices declined 34 percent.

Figure 1 also provides suggestive evidence that the prices of distressed sales have deviated from nondistressed sales, especially around and during the bust. Movements in the two indexes are quite similar until 2004. At that time, which is near the end of the housing boom, the price index including distressed sales rose faster than the corresponding index excluding distressed sales. This puzzling fact has not been addressed in the literature. After the peak in housing prices in April 2006, the index including distressed sales declined more rapidly than the index excluding distressed sales. In other words, sharper declines occurred in the prices of distressed property than in nondistressed property. The magnitude of this differential price behavior has drawn the attention of many researchers.

During recent years the two indexes have risen similarly. Including distressed sales, from March 2011 housing prices have risen steadily (roughly 40 percent) through May 2016. One development that differentiates the recent run-up in housing prices from previous run-ups in the postwar era is that it is not driven by increased demand for owner-occupied housing. ${ }^{9}$ The decline in homeownership rates highlighted below suggests that private and institutional investors have found opportunities to take advantage of the current environment for housing purchases.

\section{The Rise and Fall in Foreclosures}

Declining housing prices have both been caused by foreclosures and contributed to foreclosures. Figure 3 shows the rise and subsequent decline in new foreclosures during the financial crisis. From quarterly levels generally less than 0.50 percent before 2007, new foreclosures rose rapidly during 2007, 2008, and early 2009 as housing prices declined, reaching a peak of 1.5 percent in 2009:Q2. ${ }^{10}$ However, because the foreclosure process entails costs for the lender, lenders likely factor in numerous considerations in their foreclosure decisions. Negotiations with the borrower might be a preferred route for the lender.

Legal obligations also affect the results. During the bust, Mian, Sufi, and Trebbi (2015) found that those states without a judicial requirement had twice the foreclosure rates of those states with a judicial requirement. Subsequently, the national rate of new foreclosures has declined to less than 0.5 percent and has remained there since $2014 .{ }^{11}$ Coinciding with this normalization of foreclosure rates, Mian, Sufi, and Trebbi (2015) found that the foreclosure rates in judicial and nonjudicial states had converged. 


\section{Figure 3}

\section{New Foreclosures}

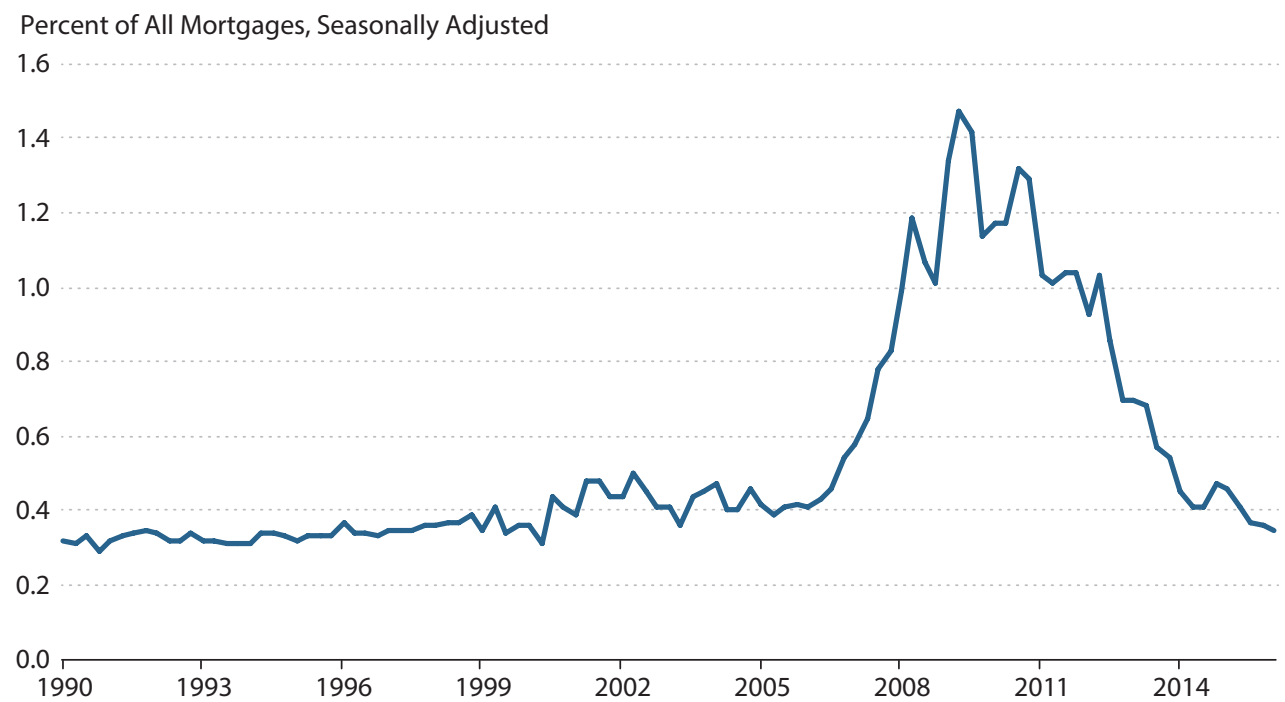

SOURCE: Mortgage Bankers Association/Haver Analytics

\section{Figure 4}

\section{Mortgages in Foreclosure}

Percent of All Mortgages, Not Seasonally Adjusted

5.6

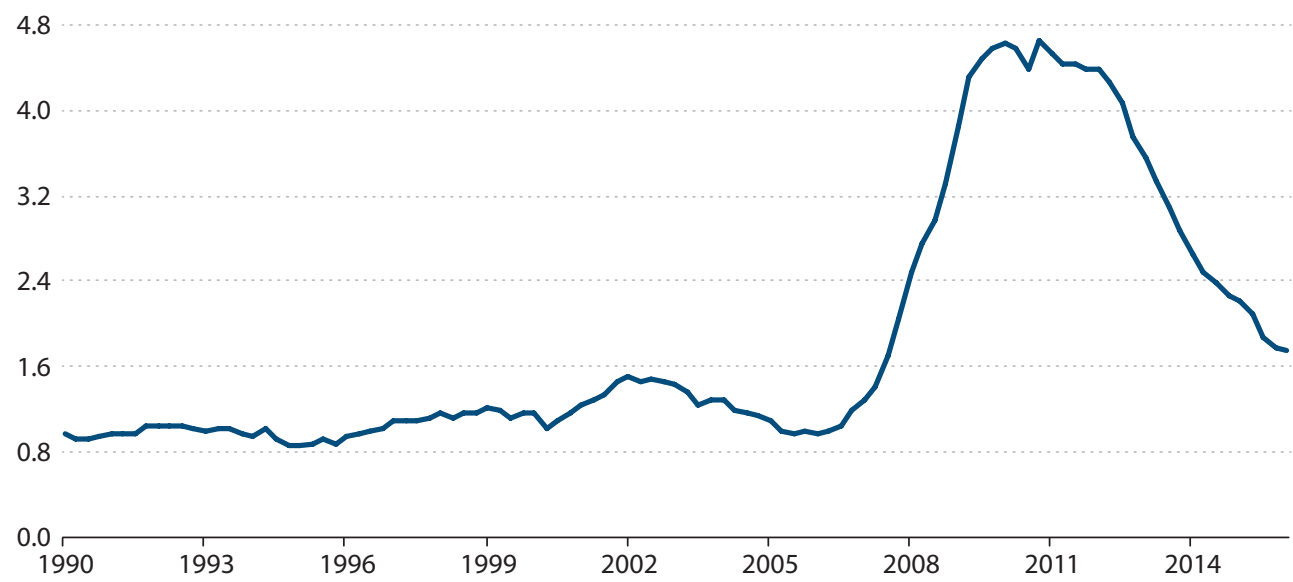

SOURCE: Mortgage Bankers Association/Haver Analytics. 


\section{Cohen, Coughlin, Yao}

Figure 4 shows another dimension of foreclosures by showing the total number of loans in the legal process of foreclosure as a percentage of the total number of mortgages in a specific quarter. From rates of roughly 1 percent, this rate rose sharply during 2006-10, peaking at 4.6 percent in 2010:Q4. While this inventory declined to 1.7 percent in 2016:Q1, it remains above the levels of the mid-2000s.

Mayer, Pence, and Sherlund (2009) explain the rise in subprime mortgage defaults and suggest that the relaxed underwriting standards-manifested most dramatically by lenders allowing borrowers to forgo down payments entirely-and stagnant to falling house prices in many parts of the country appear to be the most immediate contributors to the rise in mortgage defaults. The reason for the surge in defaults for mortgages with low or no documentation is due mostly to underwriting that had deteriorated along other dimensions. However, subprime defaults are not the entire story. Ferreira and Gyourko (2015) reinterpret the U.S. foreclosure crisis as more of a prime, rather than a subprime, borrower issue. They find that traditional mortgage default factors associated with the economic cycle, such as negative equity, completely account for the foreclosure propensity of prime borrowers relative to allcash owners and for three-quarters of the analogous subprime gap.

\section{The Rise and Fall in Homeownership}

In the mid-1990s national leaders began a broad effort to increase homeownership, which is defined as the percentage of homes owned by their occupants. This bipartisan effort began during the Clinton administration and was later embraced by the Bush administration. ${ }^{12}$ As shown in Figure 5, using seasonally adjusted rates, this effort generated increased homeownership, albeit temporarily. After maintaining a rate of roughly 64 percent for nearly 10 years, homeownership began to rise in the mid-1990s, rising in a consistent manner until reaching 69.4 percent in 2004:Q2. The demand associated with this rising homeownership propelled a housing market boom that stimulated rapid growth overall in the United States during this period. With the advent of the housing crisis and recession, however, homeownership began a nearly continuous descent that led to its lowest level in the past 36 years, 63.1 percent in 2016:Q2.

This declining homeownership leads to many questions, none of which we examine thoroughly here. For example, what is a normal homeownership rate? The housing bubble suggests that 69.4 percent in 2004:Q2 is abnormal. Thus, one should expect the rate to be lower than 69.4 percent, but how much lower? Also, are the rates in the mid-1990s (i.e., prior to the housing boom) a reasonable guide? If so, then rates of roughly 64 percent are reasonable. A related question concerning homeownership, especially if one considers the current homeownership rate to be too low, is why more renters aren't becoming homeowners. Fuster, Zafar, and Cocci (2014) explore whether there might be changed attitudes toward housing or whether the answer might be due to a combination of low incomes, weak personal finances, and difficulties in securing mortgages. Their conclusion is that the latter combination of factors is more accurate. 


\section{Figure 5}

\section{Homeownership Rate}

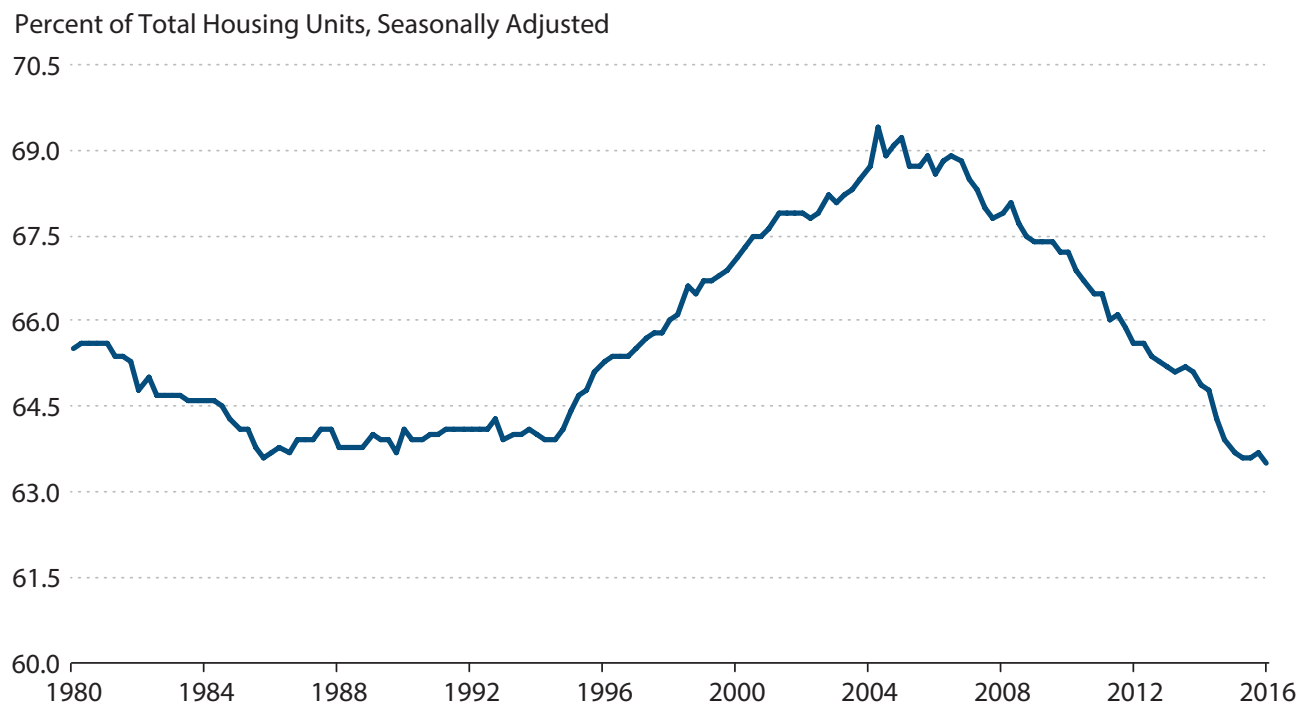

SOURCE: Census Bureau; FRED ${ }^{\circledR}$, Federal Reserve Bank of St. Louis

\section{Figure 6}

\section{Housing Completions}

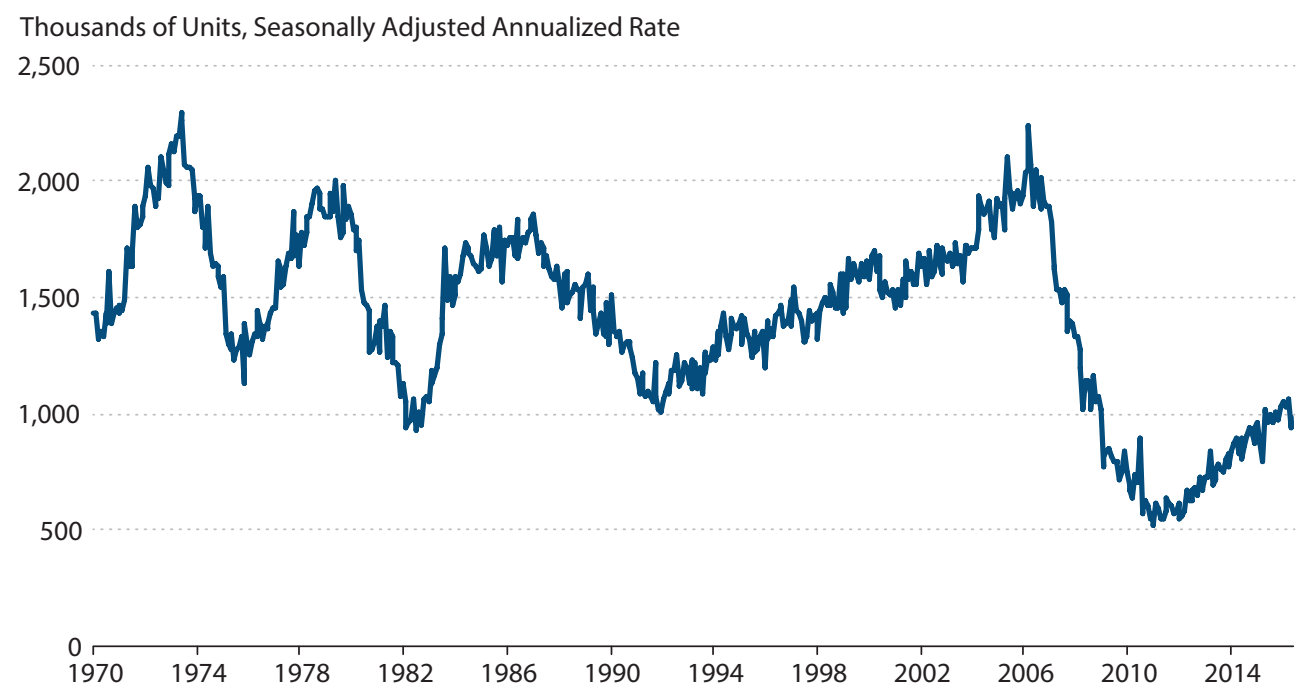




\section{Figure 7}

\section{Single-Family Housing Completions}

Thousands of Units, Seasonally Adjusted Annualized Rate 2,500

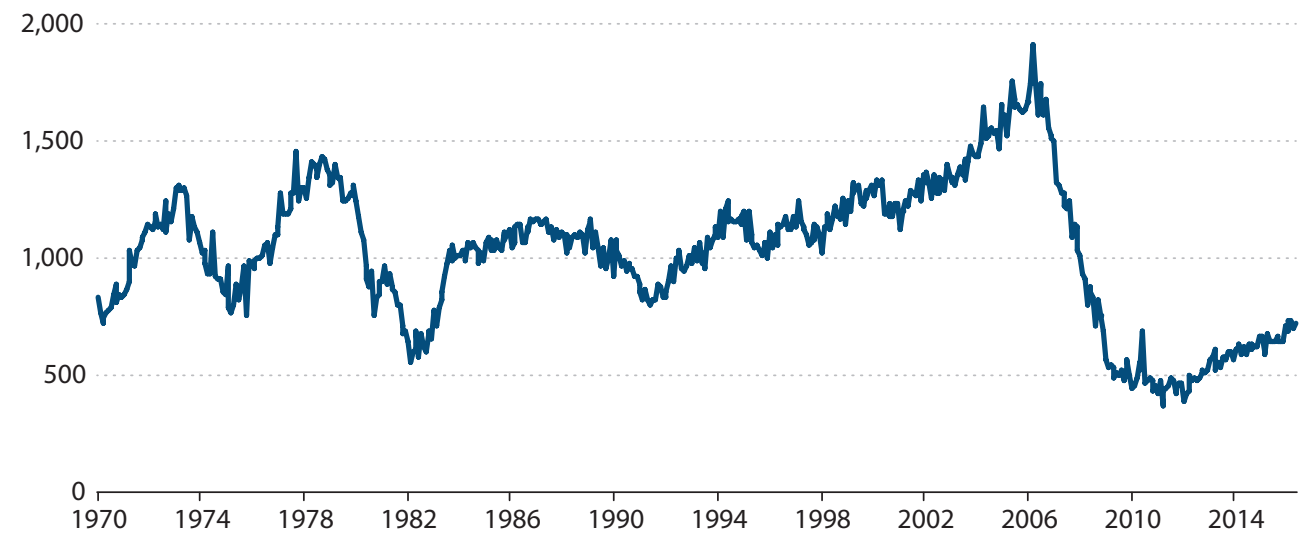

SOURCE: Census Bureau; FRED ${ }^{\circledR}$, Federal Reserve Bank of St. Louis.

\section{Figure 8}

\section{Multifamily Housing Completions}

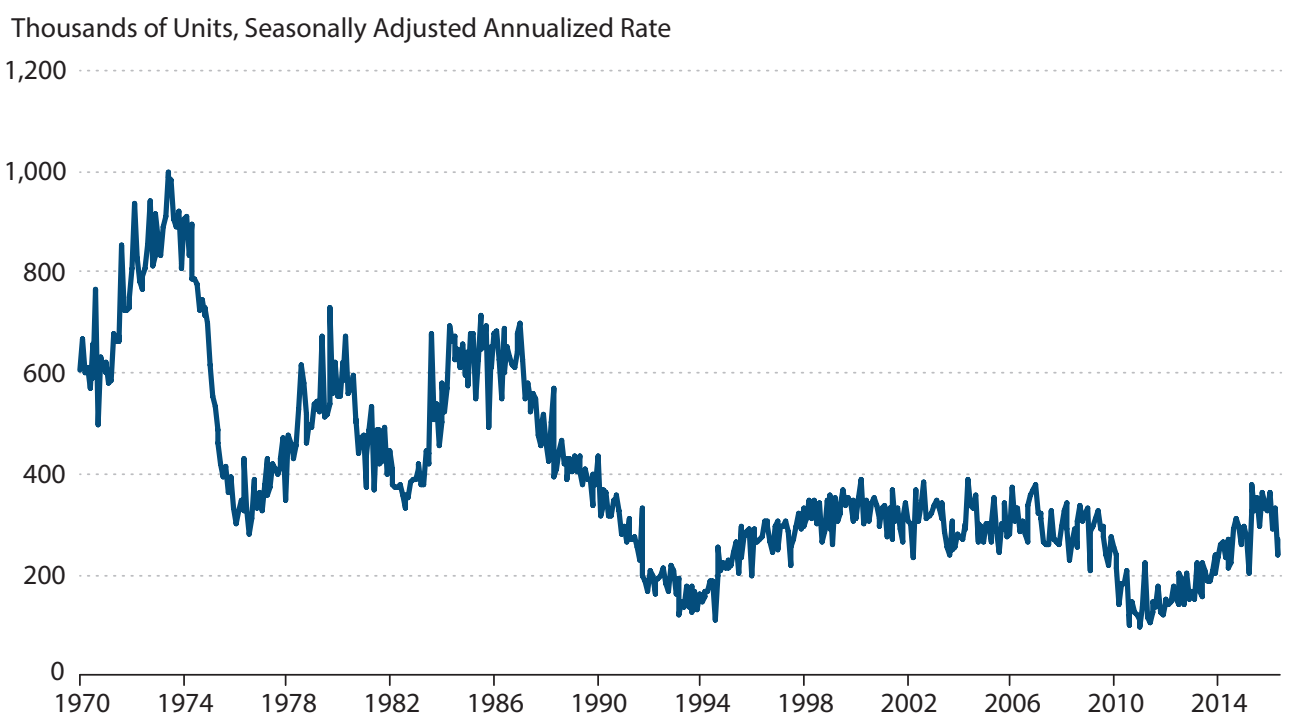

SOURCE: Census Bureau; FRED ${ }^{\circledR}$, Federal Reserve Bank of St. Louis. 


\section{Figure 9}

\section{New Single-Family Home Sales}

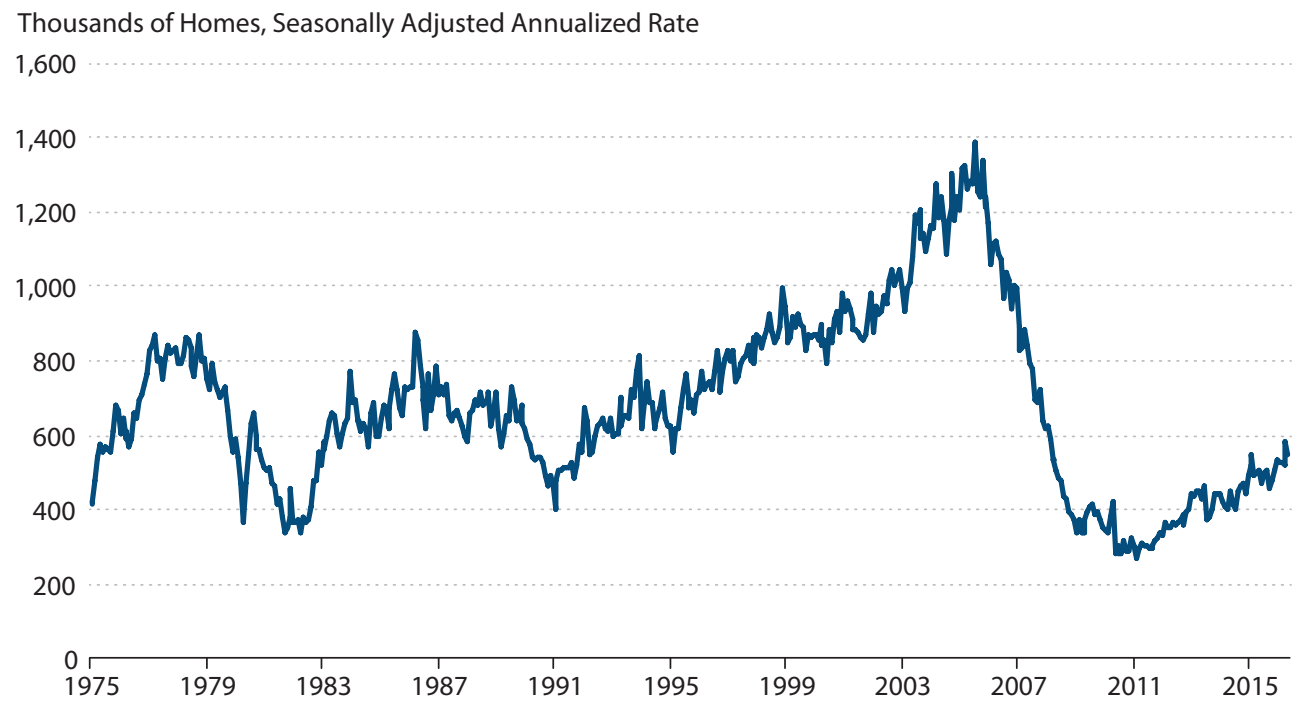

SOURCE: Census Bureau; FRED ${ }^{\circledR}$, Federal Reserve Bank of St. Louis.

\section{Figure 10}

\section{Existing Single-Family Home Sales}

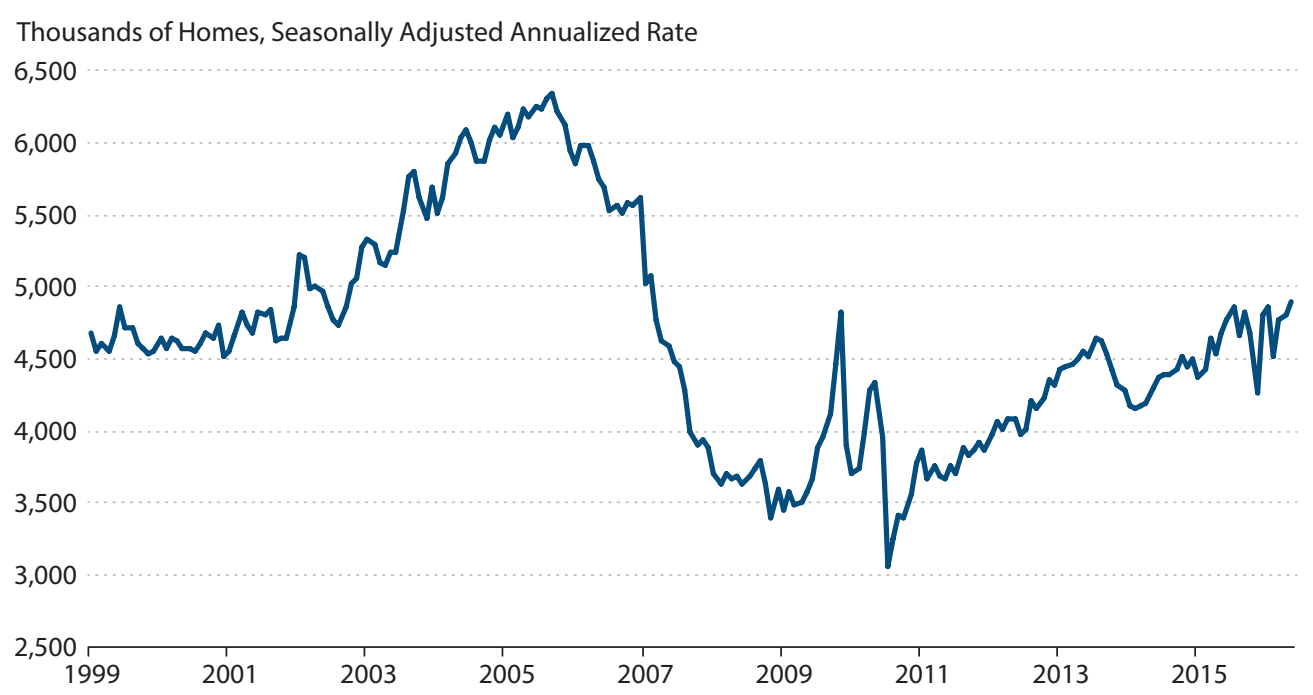




\section{Cohen, Coughlin, Yao}

\section{Changes in Construction of Single-Family Versus Multifamily Housing}

Not surprisingly, housing construction activity has mirrored the boom and bust in housing prices. Housing construction trended upward during the boom and dropped precipitously during the bust. Moreover, the recovery of housing construction from the housing/financial crisis has been slow. Figure 6 shows that housing completions have trended upward since early 2011, but that current levels remain far below the levels in the late 1990s/early 2000s.

As the current expansion continues, one might anticipate that the long-run prospects are much more favorable for multifamily housing than single-family housing. As stressed by Rappaport (2013), reduced population growth, which tends to reduce the demand for housing, and the aging of the Baby Boomers, which tends to shift demand toward multifamily from single-family housing, are key demographic factors supporting such an outlook. Figures 7 and 8 indicate that construction has shifted in such a direction. As shown by Figure 7, completion of single-family structures has increased only marginally since 2010, while Figure 8 shows that the completion of multifamily structures has increased substantially. Moreover, the single-family completions remain far below levels prior to the boom, while multifamily completions have returned to levels comparable to those seen during the early and mid-2000s.

\section{Housing Sales}

The relatively low levels of completed single-family houses are, not surprisingly, reflected in the sales of new, single-family houses. Despite some recovery in recent years, Figure 9 shows that such sales remain weak compared with the levels in the late 1990s/early 2000s. In terms of sales of existing single-family houses, as shown in Figure 10, the recovery has been far from steady but has reached levels existing in the late 1990s/early 2000s.

\section{EXAMINING FORECLOSURES: SOME BASIC ISSUES}

Statistical evidence reveals a negative correlation between foreclosures and house prices. In other words, foreclosures increase (decrease) when house prices decrease (increase). A simple correlation, however, does not answer very basic questions about the direction of causality. Both researchers and policymakers would like answers to the following questions: (i) Do declining house prices cause increased foreclosures? (ii) Do increased foreclosures cause declining house prices? It is easy to provide reasons to suggest that the answer to both questions is yes. If that is the case, then any estimation of the impact of declining house prices on foreclosures or the impact of foreclosures on house prices must address this possibility. ${ }^{13}$ This issue is discussed in more depth later when we examine specific studies.

If the answer to either of these questions is yes, then the quantitative relationship is also of interest. For example, if housing prices decline by a given percentage, what is the associated percentage increase in foreclosures? Similarly, what is the impact of a foreclosure on the price of the foreclosed house as well as on the prices of nearby houses? Furthermore, understanding the underlying mechanisms that connect foreclosures and prices can be useful for designing policy remedies. This topic is discussed immediately below. The answer to the first question is likely yes because declines in house prices contribute to a rise in foreclosures by 
putting more homeowners underwater. However, because the foreclosure process is costly and various financial conditions and expectations influence both borrower and lender behavior, being underwater is not a sufficient condition for foreclosure.

Concerning the second question, if increased foreclosures cause declining house prices, the following questions come to mind: What mechanisms produce this result? Also, is the decline in price restricted to the foreclosed property or are the values of nearby homes affected as well? With respect to the foreclosed property itself, at issue is whether the discount is due to a "stigma effect" or a "proxy effect." The former reflects a discount for no reason other than the status of the property as foreclosed. Meanwhile, the proxy effect refers to a discount caused by other characteristics that may affect prices negatively, such as deteriorated physical condition of the property and/or neighborhood conditions. Moreover, sellers of foreclosed or soonto-be-foreclosed properties may be highly motivated (i.e., have a lower reservation price or accept a lower selling price) because of a desire for shorter marketing time, lower direct and indirect carrying costs of the property, or the seller's need for liquidity.

Regarding the impact on nearby property, one possibility is that foreclosed properties are a disamenity in that they can be an eyesore (because of a lack of maintenance) or induce crime and vandalism. ${ }^{14}$ A second possibility is through a competitive effect. A foreclosed property adds to the supply of houses available for purchase and this increased supply can lead to lower prices. Would one expect the foreclosure effect to be temporary or permanent? After the foreclosed property is sold, the eyesore/crime issues should be eliminated, but is there a lasting neighborhood effect?

An article relevant to most of the econometric studies that we examine is Coulson and Zabel (2013). Their focus is on the consequences of disequilibrium for hedonic estimations. ${ }^{15}$ Given the large number of foreclosures during 2007-11, it is reasonable to argue that during recent years the housing market in many cities was not in equilibrium. These authors suggest several approaches for controlling for potential disequilibria in hedonic housing price models. ${ }^{16}$ First, a dummy variable can be added to the hedonic house price regression, which equals 1 if a property is a foreclosure and 0 otherwise. This foreclosure dummy can also be interacted with the other explanatory variables in the hedonic regression to control for the disequilibrium impacts on the housing characteristics and other neighborhood amenities/disamenities. Finally, a variable can be added to represent the distance from other foreclosures, which can control for disequilibria resulting from large numbers of nearby foreclosures. These methods are closely related to our discussion in the following section on foreclosures and house prices.

\section{The Impact of Changing Housing Prices on Foreclosures}

Foreclosures are important events that define the ultimate default. The literature on the determinants of mortgage default has been evolving for 30 years. Foster and Van Order (1984, 1985) were among the first to model default as a "put option." 17 When a homeowner has a mortgage and can extinguish his or her obligation by relinquishing the house to the lender, the owner has a put option as well as equity in the house. The put option's value is a function of the drift and volatility of house prices: It is more valuable when house prices are more likely 


\section{Cohen, Coughlin, Yao}

to fall, and more valuable when house prices are more volatile. That is because, under both circumstances, the probability that the house will be worth less than the mortgage, and therefore in the money, is greater. The Foster and Van Order articles used house price volatility as a covariate for predicting default and found it was a significant and important predictor of default. Many subsequent articles recognize a put option in the money is only a necessary, but not sufficient, condition of default and identify other factors besides home prices that explain the default. ${ }^{18}$

Gerardi, Shapiro, and Willen (2008) found that price declines beginning in the summer of 2005 were the dominant factor in causing a large increase in foreclosures during the downturn (2006 and 2007) for subprime borrowers in Massachusetts. This focus on subprime borrowers is partially due to the fact that homeowners with subprime mortgages are six times more likely to end up in foreclosure than those with prime mortgages. Similarly, Bajari, Chu, and Park (2008) found that changing home prices were a significant determinant of the probability of default of subprime and Alt-A mortgages nationwide. ${ }^{19}$

In another study focused on property in Massachusetts, Fisher and Lambie-Hanson (2012) study a suburb of Boston-Chelsea, Massachusetts-and assess how various factors, including house prices and whether properties are investor owned, affect the probability of foreclosure. They find that local investor-owned properties had a foreclosure rate that was nearly double that of owner-occupied and nonlocal investment properties. ${ }^{20}$ They also find a lower foreclosure probability when there is greater house price appreciation (and vice versa).

While declining housing prices contribute to homeowner distress and, therefore, are likely to be associated with mortgage default and foreclosure, the existing literature reveals that mortgage default is a nuanced topic. Theory and empirical evidence suggest that negative home equity is necessary, but not sufficient, for triggering a default. In other words, not all households with negative home equity end up in default. For example, Foote, Gerardi, and Willen (2008), using a dataset of Massachusetts homeowners, found that fewer than 10 percent of borrowers likely to have had negative equity at year-end 1991 actually experienced a foreclosure in the following three years. As such, one needs a model of the default decision to underpin the empirical analysis of the connection between housing prices and distressed sales. Numerous models have been developed; however, a thorough scrutiny of these models is beyond the scope of this review. ${ }^{21}$ We restrict our analysis to selected results that provide some insights into the nuances.

One idea that has been explored is the "double-trigger" theory of default. Default is said to be triggered by coinciding events-the borrower experiences both negative equity and an adverse life event, such as a job loss. However, as stressed by Foote, Gerardi, and Willen (2008) and others, the double-trigger theory has been found to be lacking as a sufficient explanation for defaults. In other words, the existence of the two triggers does not guarantee default. Thus, one must provide additional theory concerning the conditions under which the double-trigger model is likely to fail. Given forward-looking agents, the expected changes in a house's price are likely to play a key role in a household's default decision. An expectation of an increasing price is likely to deter a default, while an expectation of a decreasing price is likely to increase the probability of default. 
Credit constraints are another factor that can play a role in the default decision. Campbell and Cocco (2015) find that households with high loan-to-value ratios at mortgage origination are more likely to experience negative home equity when house prices decline. The level of negative home equity that produces a default depends on the extent to which households are borrowing constrained. Households with high loan-to-income ratios are subject to tighter borrowing constraints. Across mortgage types, defaults by households with adjustable-rate mortgages increase when nominal interest rates increase and when these households suffer adverse idiosyncratic labor income shocks. Defaults by households with fixed-rate mortgages are higher when interest rates and inflation are low. Finally, interest-only mortgages trade off an increased likelihood of negative home equity against a relaxation of borrowing constraints.

Guiso, Sapienza, and Zingales (2013) use survey data to measure households' propensity to default on underwater mortgages even if they can afford to pay them (strategic default). They find that homeowners' willingness to default increases in both the absolute and the relative size of the home equity shortfall. They also find that this willingness is affected by both pecuniary and nonpecuniary factors, such as views about fairness and morality.

Gerardi, Herkenhoff, Ohanian, and Willen (2015) find that households experiencing a job loss, divorce, or large medical expenses are more likely to default. However, a larger percentage of financially distressed households do not default. For example, 80 percent of unemployed households with negligible savings (i.e., less than one month of mortgage payments) were found to be current on their mortgage payments. Moreover, the role of strategic default appears to be minimal. First, defaulting households generally have relatively low net asset levels, and second, high-wealth households with underwater mortgages generally choose not to default.

\section{The Impact of Foreclosure on the Sales Price of the Foreclosed House}

Here we examine the effect of a foreclosure on the sales price of the distressed (foreclosed) property itself. Ideally, the estimate of the foreclosure discount would be the difference in the sales price of the house sold in a normal transaction and the sales price of the same house sold under distress. Obviously, both prices cannot be observed. This leads to the classic "treatment effect" problem.

A normal transaction implies that the transaction would be undertaken at fair market value. ${ }^{22}$ Fair market value is the price that would occur in a competitive housing market. A competitive housing market is characterized by many buyers and sellers, relevant information that is equally available to buyers and sellers, and access to financial resources without regulatory or institutional barriers. In addition, related to the previous characteristics, houses must be on the market for a sufficient period to allow for a market determination of the equilibrium price.

A forced sale associated with a foreclosure does not meet the necessary conditions for a competitive housing market. Unlike a voluntary transaction, in a forced sale one of the participants is not entirely a willing participant. Moreover, the buyer possesses less information about the property than in a normal housing market transaction. This lack of information could be due to a time constraint on the date of sale or there could be sale procedures that 


\section{Cohen, Coughlin, Yao}

preclude on-site inspections of the property. Forced sales are also not as widely advertised as normal sales. Finally, forced sales differ from normal sales in that financing options are more limited for the former than the latter. All these considerations tend to reduce the price of forced sales relative to the price that would occur in a competitive market. ${ }^{23}$

Generally, the mortgagee acquires the residential property through the foreclosure process. One could argue that these REO properties should sell for their market value. A fundamental question is whether the bank or financial institution would behave in the same manner as the seller in a normal transaction. Possibly the bank or financial institution would value the time on the market more highly than a normal seller. One simple reason is that the bank or financial institution is holding a vacant property, while that may not be the case in many normal transactions. If so, this consideration could lead to a lower price. However, such a price difference does not necessarily indicate the existence of potential excess returns.

At issue is whether the discount is due to a stigma effect or a proxy effect. As discussed earlier, the former reflects a discount for no reason other than the status of the property as foreclosed. No characteristics differentiate the foreclosed property from a non-foreclosed property. A large stigma effect suggests the possibility of excess returns for potential buyers who can purchase and then resell quickly, capturing a windfall. While housing markets are not perfectly efficient, it is hard to believe that such returns could be large. Meanwhile, the proxy effect refers to a discount related to other characteristics that may affect price negatively, such as a deteriorated physical condition and/or neighborhood conditions. One reason that foreclosed properties sell at a discount is that they are in worse condition than nearby properties. Moreover, sellers of foreclosed or to-be-foreclosed properties may be highly motivated (i.e., have a lower reservation price or accept a lower selling price) because of their desire for shorter marketing time, lower direct and indirect carrying costs of the property, or the seller's need for liquidity. As a result, the foreclosure status variable is a proxy for other omitted variables. Omitted variables may produce a biased estimate of a pure foreclosure (stigma) effect. ${ }^{24}$ For example, vacant houses sell for lower prices. To the extent that foreclosed houses are more likely vacant, omitting this variable can lead to a biased foreclosure effect. Another example involves cash transactions, which often lead to lower sale prices. If foreclosed sales tend to consist of relatively more cash sales than non-foreclosed sales, then omitting this variable can lead to a biased foreclosure estimate.

Zabel (2014) develops a dynamic model of the housing market where he allows for the possibility of vacancies that are part of the stochastic process in the regression's error terms, while controlling for excess demand and excess supply (i.e., disequilibria). When he estimates his model with annual metropolitan statistical area (MSA) data for the United States for the years 1990-2011, he finds that both excess demand and excess supply respond more to changes in the market during 2006-11. This model sheds light on the issue of disequilibria in housing markets and how prices respond to these disequilibria.

An additional complication is that lenders face a choice concerning how to handle defaults by way of short sales, sales during foreclosures, or REO sales. Clauretie and Daneshvary (2011) find that the price discount is highest for REO transactions (13.5 percent) and is smallest for short sales (5.6 percent). However, there are also time-on-the-market costs. The short sales option has the highest costs associated with marketing time. 
Cohen, Coughlin, Yao

\section{Table 1}

\section{Own Price Decline of a Foreclosure}

\begin{tabular}{|c|c|c|c|c|}
\hline Authors (date) & Geographic area & Period & Estimation & 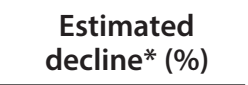 \\
\hline Shilling, Benjamin, \& Sirmans (1990) & Baton Rouge, LA & 1985 & OLS & 21.3 \\
\hline Forgey, Rutherford, \& VanBuskirk (1994) & Arlington, TX & 1991-93 & OLS & 20.4 \\
\hline Hardin \& Wolverton (1996) & Phoenix, AZ & 1993-94 & OLS & 22.2 \\
\hline Springer (1996) & Arlington, TX & 1989-93 & OLS & 3.7 \\
\hline Carroll, Clauretie, \& Neill (1997) & Las Vegas, NV & $1990-93$ & OLS & 0.17 to $2.6^{+}$ \\
\hline Pennington-Cross (2006) & United States & 1995-99 & Calculations $^{\ddagger}$ & $2^{\S}$ \\
\hline Clauretie \& Daneshvary (2009) & Las Vegas, NV & 2004-07 & GS2SLS & 7.5 \\
\hline Campbell, Giglio, \& Pathak (2011) & Massachusetts & $1987-2008$ & OLS & 27.6 \\
\hline Clauretie \& Daneshvary (2011) & Las Vegas, NV & 2007-08 & $3 S L S$ & 13.5 \\
\hline Harding, Rosenblatt, \& Yao (2012) & 13 MSAs & $1990-2008$ & Various & No excess returns \\
\hline Siebert (2015) & Hollywood, FL & $2000-08$ & WLS & 4.7 \\
\hline Siebert (2015) & Fort Lauderdale, FL & $2000-08$ & WLS & 12 \\
\hline Siebert (2005) & Lafayette, IN & $2000-08$ & WLS & 16.1 \\
\hline
\end{tabular}

NOTE: GS2SLS, generalized spatial two-stage least squares; OLS, ordinary least squares; 3SLS, three-stage least squares; WLS, weighted least squares. * The estimate presented is not the only estimate contained in these articles. Our goal is to provide comparability across studies in terms of the focus of our review. We present exact estimates-by calculating $100^{*}\left(e^{b}-1\right)$, where $b$ is the coefficient associated with the foreclosure dummy in log-linear models, in all instances where such a calculation is applicable. Any discrepancies between the estimates provided and those in the corresponding articles can be attributed to this conversion.

† The estimates were statistically insignificant.

₹ The author calculates the percent appreciation in house prices in a foreclosed home's MSA from the origination of the foreclosed home's mortgage through the post-foreclosure sale of the home, and subtracts from that the foreclosed home's price appreciation over that period to obtain a measure of the appreciation discount for the home. The author then calculates the average discount.

$\S$ The author reports an appreciation discount of 22 percent, which results in an overall price discount of 2 percent for the sample average MSAlevel appreciation from mortgage origination through post-foreclosure sale (10 percent).

Estimates of the foreclosure discount in the literature we survey range from near zero to 28 percent across studies that cover different geographic areas in the United States and span various years-as early as 1985 up through 2008. These estimates are summarized in Table 1, and we elaborate on the details of some of these studies below.

We briefly examine a number of the early studies on the foreclosure discount. ${ }^{25}$ Shilling, Benjamin, and Sirmans (1990) find a 21.3 percent discount on foreclosed condos in Baton Rouge, Louisiana, in 1985. They stress the sellers' desire to sell quickly to avoid carrying costs and the buyers' requirement of a discount to compensate for carrying costs prior to leasing. A similar discount was estimated by Forgey, Rutherford, and VanBuskirk (1994). They found a 20.4 percent discount on foreclosed single-family properties in Arlington, Texas, from 1991 to 1993.

Hardin and Wolverton (1996) also estimated a foreclosure discount in excess of 20 percent. They found a 22 percent discount on foreclosed apartment complexes in Phoenix, 


\section{Cohen, Coughlin, Yao}

Arizona, in 1993-94, which they attribute to seller motivation. This finding is in contrast to that of Springer (1996), who found a 4 percent foreclosure discount on single-family houses in Arlington, Texas. This study accounted for motivation of the seller, but not endogeneity of time on the market, property condition, or cash sales. Carroll, Clauretie, and Neill (1997) found a discount of 0.17 to 2.6 percent on residential properties in Las Vegas, Nevada, during 1990-93. As a foreshadowing of the conclusions in Clauretie and Daneshvary (2009), they argue that the larger estimates in other articles result from failing to control for neighborhood quality. In a study of foreclosed single-family properties nationwide from 1995-99, PenningtonCross (2006) found a 2 percent price discount that resulted from a 22 percent discount in the appreciation of foreclosed homes, relative to their respective MSAs, from the origination date of the mortgage through the post-foreclosure sale of the property.

Clauretie and Daneshvary (2009) examined distressed sales in Las Vegas for the period covering November 2004 through November 2007. They show that by accounting for certain variables, such as the physical condition of the property and the relationship between marketing time and price, plus correcting for two types of spatial price interdependence, the previous estimates of the foreclosure discount are biased high. ${ }^{26-28}$ In their preferred estimation, which controls for property condition, occupancy status, and payment method, in addition to commonly controlled for characteristics, the foreclosure effect is 7.5 percent. Without these additional controls, the foreclosure effect is 10 percent. Thus, the size of potential excess returns is much smaller than other studies have suggested.

Campbell, Giglio, and Pathak (2011), using a typical hedonic regression, find large foreclosure discounts, about 28 percent on average, with larger discounts for houses in low-quality neighborhoods. In a more recent study in this area, Siebert (2015) found that foreclosed homes in Hollywood, Florida; Fort Lauderdale, Florida; and Lafayette, Indiana, sold for 4.7 percent, 12 percent, and 16.1 percent less, respectively. The vast majority (e.g., 92 percent) of these differences is the result of a proxy effect of lower quality. Therefore, very little relates to a motivation by REO owners for a quick sale to avoid forgone investment opportunities. Siebert (2015) also found much heterogeneity across house size, price, and geographic area. Also, for a topic we examine next, Siebert found that the existence of any nearby foreclosed homes has a negative impact on the values of non-foreclosed properties, with the effect ranging from 0.8 percent to 4.7 percent.

Large discounts - certainly those in excess of 20 percent-suggest the possibility of large returns from buying and then shortly thereafter reselling the property. Using a large sample of repeat sales pairs, Harding, Rosenblatt, and Yao (2012) find that REO purchasers do not earn excess returns-in other words, the real estate market operates efficiently. Thus, there is no evidence that banks are selling houses at fire-sale prices. REO properties and buyers differ from their counterparts in the non-distressed market segment (which can be considered an "endowment effect"), and the attribute prices of REO properties differ from those of nondistressed properties (i.e., a "coefficient effect"). Each of these factors accounts for roughly half of the price difference. 


\section{The Impact of Foreclosures on the Sales Prices of Nearby Houses}

From a microeconomic perspective, increased homeowner distress (foreclosures) could be causing declining housing prices of nearby properties. ${ }^{29}$ However, in the absence of a foreclosure discount, there is no reason to expect a negative price impact in the form of an externality. Given a foreclosure discount, a key empirical challenge is disentangling the supply effect of foreclosures from the potential disamenity effect of foreclosures. Note that the disamenity can be viewed as a reduction in neighborhood quality. However, the supply effect of another house on the market might not be fully portrayed by the characteristics of the house if the house has been allowed to physically deteriorate. This underscores the importance of the assumption that hedonic house price models represent equilibrium prices. The literature reveals much diversity in terms of the geographic (i.e., local) and temporal (i.e., up to 5 years) impacts of foreclosures. Nearby foreclosures do decrease the sales prices of nearby nondistressed properties. A standard finding is that this effect decreases rapidly over both distance and time. The variation in foreclosure discounts and spillover estimates is a result of differences in data, geographies and time periods, and the underlying empirical models. ${ }^{30}$ The use of a repeat sales approach is more appropriate than a standard hedonic approach; however, modified hedonic approaches can generate insights when repeat sales data are unavailable.

One of the first studies to estimate the foreclosure externality was that of Immergluck and Smith (2006a) (Table 2). Focusing on Chicago in the late 1990s, they estimated the effects of foreclosures 1 to 2 years after they occurred and found that a foreclosure causes a 0.9 percent decline in house values for all homes within a $1 / 8$-mile radius. ${ }^{31}$ The percentage impact is larger for low- and moderate-income areas. A shortcoming of this article, noted by Lee (2008), is the lack of adequate handling of reverse causation.

An important issue is how the price impact of foreclosures might change as the number of foreclosures in a neighborhood increases. Using data on New York City, Been (2008) found that the marginal spillover effects of additional properties with pending foreclosure petitions tend to diminish. This negative effect shrinks with both time and distance. Been's work on how the price effect changes with time and distance has been extended by Lin, Rosenblatt, and Yao (2009). They found that for conforming mortgages, foreclosures have a clear negative impact on prices of local houses. This effect is larger during a downturn than during other times, which suggests one must control for the stage of the housing cycle. Lin, Rosenblatt, and Yao (2009) found their largest effect of foreclosure of 8.7 percent for closely neighboring properties during a bust year: This effect diminishes with distance and time but can last up to five years after the foreclosure.

Further extensions of this literature were made by Leonard and Murdoch (2009), who argue that neighborhood quality can be viewed as a local public good and is an important determinant of housing prices. Changes in nearby foreclosures indicate changes in neighborhood quality. In the Dallas, Texas, area they found a negative effect of housing distress on prices, an effect that decreases as distance from the foreclosed property increases. In models controlling for both spatial dependence in housing prices and in the errors, the authors find that an additional foreclosure within 250 feet of a sale affects the selling price of an average 


\section{Cohen, Coughlin, Yao}

\section{Table 2}

Price Decline of a Nearby Foreclosure*

\begin{tabular}{|c|c|c|c|c|c|c|c|}
\hline Authors & Area & Proximity $^{\dagger}$ & $\begin{array}{c}\text { Time } \\
\text { proximity }\end{array}$ & Period ${ }^{\S}$ & Estimation & Interpretation" & $\begin{array}{c}\text { Estimated } \\
\left.\text { decline" }^{\#} \%\right)\end{array}$ \\
\hline $\begin{array}{l}\text { Immergluck \& Smith } \\
\text { (2006a) }\end{array}$ & Chicago & $660 \mathrm{ft}$ & $\begin{array}{l}\text { Foreclosure } \\
2 \text { yrs before }\end{array}$ & Late 1990s & OLS & Per foreclosure & 0.9 \\
\hline Been (2008) & New York & $500 \mathrm{ft}$ & $\begin{array}{l}\text { Foreclosure } \\
2 \text { yrs before }\end{array}$ & $2000-05$ & OLS & $\begin{array}{l}\text { First/second } \\
\text { foreclosure (D) }\end{array}$ & 1.8 \\
\hline $\begin{array}{l}\text { Schuetz, Been, \& Ellen } \\
\text { (2008) }\end{array}$ & New York & $250 \mathrm{ft}$ & $\begin{array}{l}\text { Foreclosure } \\
18 \text { mos before }\end{array}$ & $2000-05$ & OLS & Any foreclosure (D) & 0.8 \\
\hline $\begin{array}{l}\text { Lin, Rosenblatt, \& Yao } \\
\text { (2009) }\end{array}$ & Chicago & $330 \mathrm{ft}$ & $\begin{array}{l}\text { Foreclosure } \\
2 \text { yrs before }\end{array}$ & 2004-06 & Heckman & Per foreclosure & 8.7 \\
\hline $\begin{array}{l}\text { Lin, Rosenblatt, \& Yao } \\
\text { (2009) }\end{array}$ & Chicago & $330 \mathrm{ft}$ & $\begin{array}{l}\text { Foreclosure } \\
2 \text { yrs before }\end{array}$ & 2001-03 & Heckman & Per foreclosure & 5.0 \\
\hline $\begin{array}{l}\text { Leonard \& Murdoch } \\
\text { (2009) }\end{array}$ & Dallas & $250 \mathrm{ft}$ & $\begin{array}{l}\text { Foreclosure in } \\
\text { same calendar yr } \\
\text { or yr before }{ }^{* *}\end{array}$ & 2005-06 & GMM & Per foreclosure & 0.83 \\
\hline $\begin{array}{l}\text { Rogers \& Winter } \\
\text { (2009) }\end{array}$ & St. Louis & $600 \mathrm{ft}$ & $\begin{array}{l}\text { Foreclosure } \\
6 \text { mos before }\end{array}$ & $1998-2007$ & GMM & First foreclosure & 0.66 \\
\hline $\begin{array}{l}\text { Harding, Rosenblatt, } \\
\& \text { Yao (2009) }\end{array}$ & $\begin{array}{c}140 \\
\text { Zip codes }\end{array}$ & $300 \mathrm{ft}$ & $\begin{array}{l}\text { Foreclosure } \\
3 \text { mos before }\end{array}$ & $1989-2007$ & OLS & Per foreclosure & 1.1 \\
\hline $\begin{array}{l}\text { Campbell, Giglio, } \\
\text { \& Pathak (2011) }\end{array}$ & Massachusetts & $260 \mathrm{ft}$ & $\begin{array}{l}\text { Foreclosure } \\
1 \mathrm{yr} \text { before }\end{array}$ & $1987-2009$ & $\begin{array}{l}\text { Weighted } \\
\text { OLS }\end{array}$ & Per foreclosure & $0.85^{t+}$ \\
\hline $\begin{array}{l}\text { Daneshvary \& } \\
\text { Clauretie (2012) }\end{array}$ & Las Vegas & $528 \mathrm{ft}$ & $\begin{array}{c}\text { REO sale } \\
3 \text { mos before }\end{array}$ & 2008-09 & GS2SLS & Per foreclosure & 1.1 \\
\hline $\begin{array}{l}\text { Whitaker \& } \\
\text { Fitzpatrick (2013) }\end{array}$ & $\begin{array}{c}\text { Cuyahoga, } \\
\mathrm{OH}\end{array}$ & $500 \mathrm{ft}$ & $\begin{array}{l}\text { Public sale } \\
1 \text { yr before }\end{array}$ & $2009-11$ & GMM & Per foreclosure & $4.6^{\ddagger \neq}$ \\
\hline Hartley (2014) & Chicago & $260 \mathrm{ft}$ & $\begin{array}{l}\text { Foreclosure } \\
1 \mathrm{yr} \text { before }\end{array}$ & 1999-2011 & OLS & Per foreclosure & $1.3^{\S \S}$ \\
\hline $\begin{array}{l}\text { Anenberg \& Kung } \\
\text { (2014) }\end{array}$ & $4 \mathrm{MSAs}$ & $528 \mathrm{ft}$ & $\begin{array}{l}\text { REO listed while } \\
\text { property listed" }\end{array}$ & 2007-09 & OLS & Per foreclosure & $1.6^{\# \#}$ \\
\hline $\begin{array}{l}\text { Turnbull \& } \\
\text { van der Vlist (2014) }\end{array}$ & $\begin{array}{l}\text { Orange County, } \\
\text { FL }\end{array}$ & $1,320 \mathrm{ft}$ & $\begin{array}{l}\text { Post-foreclosure } \\
\text { sale } 90 \text { days } \\
\text { before/after }\end{array}$ & $2007-12$ & OLS & Per foreclosure & $0.8^{* * *}$ \\
\hline Siebert (2015) & Florida & Neighborhood & $\begin{array}{c}\text { Same } \\
\text { calendar yr }\end{array}$ & $2000-08$ & OLS & Any foreclosure (D) & 0.8 \\
\hline Siebert (2015) & Indiana & Neighborhood & $\begin{array}{c}\text { Same } \\
\text { calendar yr }\end{array}$ & $2008-08$ & OLS & Any foreclosure (D) & 4.7 \\
\hline $\begin{array}{l}\text { Fisher, Lambie-Hanson, } \\
\text { \& Willen (2015) }\end{array}$ & Boston & $\begin{array}{c}\text { Same } \\
\text { address and } \\
\text { association }\end{array}$ & $\begin{array}{l}\text { Foreclosure } \\
\text { active at } \\
\text { sale date }\end{array}$ & $1987-2012$ & OLS & Per foreclosure & $2.5^{\ddagger \neq \neq}$ \\
\hline $\begin{array}{l}\text { Gerardi, Rosenblatt, } \\
\text { Willen, \& Yao (2015) }\end{array}$ & $15 \mathrm{MSAs}$ & $528 \mathrm{ft}$ & $\begin{array}{l}\text { REO } \\
\text { at time of sale }\end{array}$ & $2001-10$ & OLS & Per foreclosure & $1 \S \S \S$ \\
\hline
\end{tabular}


Cohen, Coughlin, Yao

\title{
Table 2, cont'd
}

\section{Price Decline of a Nearby Foreclosure*}

\author{
NOTES:
}

* The estimate presented is not the only estimate contained in these papers. Our goal is to provide comparability across studies in terms of the focus of our review.

† Proximity refers to the maximum distance, not always physical, between the properties being analyzed and nearby foreclosures.

₹ Time proximity generally refers to the maximum amount of time between some key point during the foreclosure process (including, but not limited to, the actual date of foreclosure, date of REO sale, and so on), and the sale date of the home. When the sale date of the analyzed home is not the time marker in the paper, the alternative time marker is provided. Footnotes have been added for situations in which the time proximity requires more description.

$\S$ A study's time period is considered by the authors of this paper to span the beginning to the end of the period created by overlapping the time periods for the sales data and foreclosures data used to produce the estimates.

"The interpretation column provides the proper way to interpret the estimates provided. To add additional clarity, a (D) is added when the estimate is derived from the coefficient attached to a dummy variable.

\# As in Table 1, whenever log-linear models are used, we provide exact estimates of the price effect instead of the rough estimates provided by coefficients.

** For empirical reasons, the authors used only foreclosures that occurred within the same year as a home sale (2006) and foreclosures from the previous year (2005), given that the properties foreclosed on in the previous year were also foreclosed on during the year following the home sale (2007).

${ }^{+t}$ This estimate results from using both a variable counting the number of foreclosures the year before the sale and a variable counting the number of foreclosures the year after the sale, and subtracting the former from the latter. The authors argue that the coefficient on the after variable captures the effect of economic shocks that result in a noncausal negative relationship between the number of foreclosures before a sale and the sales price. Subtracting the after-sale coefficient from the before-sale coefficient removes such shocks.

\#‡ In later models, the authors demonstrated that the reported estimate is inflated.

$\S \S$ This estimate corresponds specifically to the effect of single-family foreclosures on sales of other single-family homes. Assuming the market for housing is segmented into single-family and multifamily units, then a supply effect explains more than 90 percent of the overall price decline.

IIII The price effect is measured by estimating the change in a home's list price that occurs when an REO home is listed nearby.

\#\# The authors attribute almost all of the price decline to a supply effect. Disamenity effects were found only for neighborhoods with high housing density and low property values, and the effect was roughly 1.5 percent.

*** The estimate consists of a 0.5 percent disamenity effect and a 0.3 percent competitive effect.

${ }^{++\dagger}$ A foreclosure is active, according to the authors, during the year before the actual foreclosure date and the two years following that date.

\#\#‡ While the author produced estimates for externalities of multiple different types of foreclosed properties onto condos, this estimate specifically refers to the effect of foreclosed condos on condos in the same association and with the same address (same building). The authors argue that, because condos in the same association should be substitutes for one another, the fact that there is a very small and statistically insignificant effect on condo prices if a condo in the same association, but at a different address, is foreclosed gives evidence that this reported effect is largely a disamenity effect.

$\S \S \S$ Their models explicitly measure the effect on home price growth, and they find that such a property experiences a growth rate that is 1 percent less for each foreclosure or seriously delinquent property in excess of the numbers of such properties present when the home was sold the first time. Because the average appreciation from the first to the second sale was 0 percent, and most houses had neither a foreclosure nor seriously delinquent property nearby at the time of each sale, the 1 percent reduction in price growth can be roughly interpreted as a 1 percent reduction in sales price. 


\section{Cohen, Coughlin, Yao}

$(\$ 200,000)$ house negatively by $\$ 1,666$ (the direct effect is $\$ 1,000$, while the total effect is $\$ 1,666)$.

For St. Louis County, Missouri, Rogers and Winter (2009) found that foreclosures have a negative (1 percent or less) impact on prices. Surprisingly, the marginal impact on prices of additional foreclosures declines as foreclosures increase. They acknowledge the simultaneity issue but were unable to find an instrument for foreclosures.

In an analysis of foreclosures in New York City from 2000 to 2005, Schuetz, Been, and Ellen (2008) found that proximity to foreclosed properties was associated with reduced sales prices and that the magnitude of the discount increased with the number of foreclosed properties, albeit not in a linear manner. In addition, the authors found evidence of a threshold effect (i.e., being near a small number of foreclosed properties may not have a price impact) and found that housing prices were lower, even before the foreclosures, in neighborhoods in which foreclosures occurred. Thus, failure to control for this latter possibility will produce selection bias.

In a recent study of home prices in Massachusetts, Campbell, Giglio, and Pathak (2011) use a novel identification strategy with hedonic regressions and find that each nearby foreclosure (i.e., within a radius of 260 feet) lowers the selling price of a non-foreclosed house by roughly 1 percent or more. In another closely related article, Harding, Rosenblatt, and Yao (2009) use a repeat sales approach to address the reverse causality and simultaneity issue between local home price trends and foreclosures in the immediate neighborhood. Their estimated discount is roughly 1 percent per nearby foreclosed property. This discount tends to vanish rapidly as the distance from the distressed property increases.

Daneshvary and Clauretie (2012) use single-family detached home transactions from January 2008 through June 2009 in Las Vegas, Nevada, and find foreclosure spillover effects much larger than those found for the same market in previous studies, ranging from 1.1 percent to 2.9 percent per foreclosure. The new results are attributed to controlling for the overall trend in market prices, the neighborhood average price, and unobserved neighborhood characteristics. No additional effect from short sales is found.

Hartley (2014) argued that foreclosure externalities work through two channels: an increase in supply and a disamenity effect if the property is not maintained or is vandalized, possibly while vacant. Both of these channels are likely to have negative effects on sale prices. As a result, a failure to control for the supply effect will likely lead to an overestimate of the disamenity effect. He found that each single-family home foreclosure within 260 feet led to a 1.3 percent price reduction in single-family houses. Also, foreclosures of multifamily units do not exert spillover effects on single-family units. Assuming segmentation, then any spillover effect in an average neighborhood is almost completely the result of the supply effect.

Foreclosures have a causal effect on nearby house prices, according to Anenberg and Kung (2014). The price effects are due to competition (i.e., an additional house for sale) and disamenities. Competition effects are important in all parts of a geographic area, while disamenity effects are found only in high-density, low-price neighborhoods. Also, while REO properties have a negative impact on nearby houses for sale, the effect is only slightly more pronounced than that of non-REO sales. 
Fisher, Lambie-Hanson, and Willen (2015) find that a foreclosed condo leads to a 2.5 percent reduction in sales price for a condo in the same association and at the same address, while it has virtually no price effect for a condo in the same association but at a different address. Because condos in the same association can be considered close substitutes, the authors conclude that the foreclosure causes a price decline through a disamenity effect rather than a supply effect.

Turnbull and van der Vlist (2014) use data from Orange County, Florida. They separate the effects of foreclosures and new construction and find that nearby foreclosures reduce property prices. Their disamenity externality estimate is 0.5 percent.

Recent research has begun to take a closer look at the externality issue by attempting to estimate differences across submarkets. For example, Whitaker and Fitzpatrick (2013) estimate the impacts of foreclosures, as well as two other features of the market related to foreclosuresproperty tax delinquency and house vacancy - on the value of neighboring houses in highand low-poverty submarkets. Using sales data from low-poverty submarkets in Cuyahoga County, Ohio, the authors find that an additional property within 500 feet that is vacant or delinquent, but not foreclosed, is associated with a reduction in a neighboring house's selling price of 1 percent or 2 percent, respectively. In the same submarkets, the negative impact of a home being vacant and tax delinquent, but not foreclosed, is 4.6 percent.

Mian, Sufi, and Trebbi (2015) use the difference in state foreclosure laws to address endogeneity. They find that a one-standard-deviation increase in the average number of foreclosures per homeowner results in a 5 to 7 percent decline in house prices over two years. They use listing data to show that foreclosures lead to a net increase in housing inventory at the zip code level, and note that this finding complements the theory that foreclosures lower neighboring house prices largely through a supply effect.

Gerardi, Rosenblatt, Willen, and Yao (2015), using data covering 15 large MSAs, provide new evidence on the size and source of the externalities. They find that the temporal impact of the externality extends from the time when the borrower becomes seriously delinquent until well after the bank sells the property. ${ }^{32}$ Non-distressed properties within 0.1 miles of a seriously delinquent or foreclosed property sell, on average, for 1 percent less per distressed property. ${ }^{33}$ This decline is sensitive to the condition of the foreclosed property, with those in poor condition having a much larger negative effect ( 2.6 percent) than those in better condition. These spillovers shrink rapidly with distance and disappear completely within one year after the bank sells the property.

Our focus in this section of our review has been on the price effects of foreclosures. A closely related issue is the possibility of foreclosure contagion. Mortgage defaults are contagious if a given default increases the default probability of another mortgage on a nearby property. Harding, Rosenblatt, and Yao (2009) found that the contagion effect grows from the onset of borrower distress through the foreclosure sale, with the effect stabilizing roughly when the lender's sale to the third party occurs. The focus of Towe and Lawley (2013) is on how a foreclosed property affects the probability of foreclosure of a neighboring property. They estimate that the probability of another default increases by 18 percent. Goodstein et al. (2011), after controlling for borrower and loan characteristics, local demographic and eco- 


\section{Cohen, Coughlin, Yao}

nomic conditions, and changes in property values, find that the mortgage default probability increases by as much as 24 percent given a one-standard-deviation increase in the zip-codelevel foreclosure rate. Finally, Rauterkus et al. (2012) address whether there is a tipping point in foreclosure rates. In other words, is there a foreclosure rate above which the foreclosure rate increases at an increasing rate? If so, an area, say a neighborhood, may be at risk of failure. The authors find evidence of contagion using data for Chicago from 2003 to 2008, but it is restricted to a small subset of markets.

An important issue for policymakers is how to mitigate the impacts of any negative externality. To design effective policy instruments, it is important to explore the transmission mechanisms of foreclosure contagions. Gerardi, Rosenblatt, Willen, and Yao (2015) find that the contagion effects are worse for poorly maintained distressed properties. Their results indicate the important role of disinvestment and the value of policies to transition from delinquencies to foreclosures quickly so that normal homeowners can resume the maintenance. The implied strategy is for lenders and government to avoid fire sales or dumping foreclosures to the market all at once. Hartley's (2014) results also support the notion that a supply effect plays a more important role in the channels of contagion, while the disamenity effect is near zero.

A recent article by Cheung, Cunningham, and Meltzer (2014) examines the possible role that a homeowners association might play. A homeowners association, by monitoring foreclosed property and ensuring some minimal levels of maintenance, can reduce the magnitude of the negative externality. Properties in neighborhoods with homeowners associations were found to be less affected by homeowner distress than properties in neighborhoods without homeowner associations. Another relevant article for policymakers is by Gangel, Seiler, and Collins (2013). They found that the size of the foreclosure contagion effect is not as important for market collapse as the time a foreclosed property remains unsold (i.e., stays on the market).

\section{CONCLUDING COMMENTS}

The effect of the Great Financial Crisis on housing markets and foreclosures is a key focus of this article. Given the long-lasting effects that foreclosures can have on the health of neighborhoods, major issues of concern are what happened with respect to the spatial aspects of foreclosures and what can we learn from these effects. Increased understanding and accurate empirical relationships provide the foundations for designing policy responses.

An extensive literature exists for the three major topics examined in this article-specifically, (i) how housing price changes affect foreclosures; (ii) how a foreclosure affects the sales price of the foreclosed house; and (iii) how foreclosures in the vicinity of a property affect the sales price of this nearby house. Concerning the first major topic, declining housing prices are associated with increasing foreclosure rates; however, negative equity need not trigger a default. Various other factors, such as a job loss, a major medical issue, financing options, one's views on fairness, or housing price expectations, can also play an important role.

Our literature review has highlighted various theoretical and econometric issues that have raised doubts about the accuracy of estimated price impacts of foreclosures and led to numerous refinements of the subsequent empirical analysis. As is standard in empirical 
analyses, issues arise concerning the inclusion and exclusion of specific variables, such as those capturing housing quality and the supply effects of foreclosures. Clearly, there is potential endogeneity/simultaneity between foreclosures and sale prices, but little known effort has focused on this issue (with the exception of some research using spatial econometrics techniques, among a select few other studies).

In addition to the issue of the discount with respect to topics (ii) and (iii) above, we have motivated the issue of foreclosures and housing price studies by elaborating on the importance of considering whether or not property markets are in disequilibrium and how a researcher might control for this possibility, which was highly likely during the Great Recession. Noting that foreclosures and/or vacancies are a form of departure from equilibrium housing market conditions, Coulson and Zabel (2013) provide an excellent review of how researchers should control and have controlled for market disequilibria in the context of valuing willingness to pay for environmental quality. Some of the studies we survey have used the Coulson and Zabel (2013) prescriptions of including a dummy variable for foreclosure properties in a hedonic regression and/or including some function of distance to nearby foreclosures. Even though concern about simultaneity between house prices and foreclosures still remains, the literature has evolved in a manner that has attempted to address these issues. But there is clearly more room in the literature for simultaneity to be handled in a rigorous manner.

We have synthesized many of the estimates of the own foreclosure discount and have found this ranges between almost zero and 28 percent, with the majority of estimates greater than 12 percent. However, much remains to be learned about the fundamental determinants of this discount, especially the specifics of proxy effects. We have also compared estimates of the discount resulting from spillover effects of nearby foreclosed houses, which is much smaller than the own foreclosure discount. Specifically, the nearby foreclosure discount ranges from less than 1 percent to approximately 9 percent, with most estimates below 2 percent. This effect diminishes rapidly with distance. While nearby foreclosures are important determinants of house prices, a much more important determinant of house prices is whether a particular property is a foreclosure.

Not surprisingly, many extensions of the existing literature are possible. We have already highlighted the potential importance of handling the issues of simultaneity and market disequilibria. Two other issues are potentially very important in our view. First, the probability of a foreclosure can vary across locations in a city, and we anticipate extending the Fisher and Lambie-Hanson (2012) analysis to allow for this type of variation. Second, an examination of land value estimates, such as that of Davis and Palumbo (2008) for some major U.S. cities (including Atlanta), indicates a dramatic (and perhaps implausibly large) drop-off in land prices beginning in 2007. One might argue that foreclosures affect land or location values rather than the characteristics and value of the structure of the house. This is a topic deserving further consideration. 


\section{Cohen, Coughlin, Yao}

\section{NOTES}

1 This topic has been examined by many, including Leamer (2007) and Mian, Sufi, and Trebbi (2015).

2 While our review focuses on sales of distressed residential property, a sale is not the only outcome for a borrower in distress. For a study examining not only sales but also other possibilities, such as a loan modification, see Chan et al. (2014). According to Gerardi and Li (2010), a review of recent foreclosure-prevention programs reveals poor results in reducing foreclosures based on high rates of redefault.

3 Analyses of the effects of different laws on mortgage outcomes in foreclosure processes have become more frequent recently. A thorough analysis of this topic is beyond the scope of this article. For examples of recent papers, see Desai, Elliehausen, and Steinbuks (2013); Fitzpatrick et al. (2014); Price et al. (2015); and Mian, Sufi, and Trebbi (2015).

4 See Gerardi, Lambie-Hanson, and Willen (2013) and Cordell et al. (2015) for additional discussion of this issue.

5 Although slightly dated, some of the topics in our review have been summarized previously. For example, see Lee (2008) and Frame (2010).

6 Various house price indexes exist and these differing indexes yield slightly different results. For example, the S\&P/Case-Shiller Home Price Index peaked in February 2007.

7 While our overview is focused on the national economy, Cohen, Coughlin, and Lopez (2012) found substantial diversity across metropolitan areas during the boom and bust. During the boom, housing prices tended to rise much faster in metropolitan areas in the East and West Coast regions than in the interior. In addition, metropolitan areas with larger price booms tended to experience larger price busts. For an examination of the overall performance of metropolitan regions beginning in the early 1990s, see Arias, Gascon, and Rapach (2016).

8 Numerous references for this topic exist. Two analyses providing many references are Foote, Gerardi, and Willen (2012) and Levitin and Wachter (2012). A recent article that studies the relationship between credit supply and house prices is Favara and Imbs (2015).

9 Garriga (2013) and Molloy and Zarutskie (2013) discuss recent business investor activity in the housing market.

${ }^{10}$ Looking at the annual levels, the foreclosure rate peaked at 5.4 percent in 2009. For comparison, in the late $1990 \mathrm{~s}$ this rate averaged less than 1.5 percent and over the past four quarters (2015:Q2-2016:Q1) was 1.5 percent.

${ }^{11}$ For an overview of regional variation in subprime delinquencies rates, see Doms, Furlong, and Krainer (2007).

12 Increased homeownership enjoyed bipartisan support because it was viewed as a valuable way to build wealth and provide upward mobility. However, Bayer, Ferreira, and Ross (2016) found that minority homeowners were quite vulnerable during the bust.

${ }^{13}$ The questions highlighted above have generally been examined from a microeconomic perspective. However, using data aggregated to the state level, Calomiris, Longhofer, and Miles (2013) examine the direction of causality and the magnitudes of the impacts of shocks. They find causality in both directions. In addition, they find that increased foreclosures have a negative effect on housing prices, but that the negative impact of housing prices on foreclosures is much larger. Specifically, the impact of prices on foreclosures is 79 percent larger than the impact of foreclosures on prices. The relatively small impact of foreclosure starts on prices is noteworthy because research has tended to focus on this question as opposed to the impact of prices on foreclosures.

${ }^{14}$ Numerous studies, such as Immergluck and Smith (2006b); Goodstein and Lee (2010); Katz, Wallace, and Hedberg (2013); and Ellen, Lacoe, and Sharygin (2013), have found a connection between foreclosures and various crimes. In a recent article, Cui and Walsh (2015) find that the foreclosure itself has no effect on crime, but rather that foreclosed houses that become vacant are associated with increased violent crime. Once a house is reoccupied, the crime effects dissipate.

${ }^{15}$ Hedonic regressions are used commonly in housing price studies. In a hedonic housing price regression, the house is decomposed into its individual characteristics (including characteristics associated with its location) and then estimates of how each characteristic contributes to the equilibrium price of the house are generated.

${ }^{16}$ A key point of Coulson and Zabel (2013) is that the hedonic housing price approach, as proposed by Rosen (1974), assumes markets are in equilibrium. Therefore, hedonic housing price estimates generated for time periods where there is disequilibrium in housing markets can be biased. 
${ }^{17}$ Formally, a put option gives the owner the right, but not the obligation, to sell an asset at a specified price by a predetermined date to a given party.

18 Kau, Keenan, and Kim (1993) and Kau and Keenan (1999) show that even in the absence of transactions costs, borrowers will not necessarily default immediately when the option is in the money. A further contribution by Deng, Quigley, and Van Order (2000) shows that default models are best modeled in a competing-risk framework, where default competes with prepayment.

${ }^{19}$ An Alt-A mortgage is a type of U.S. mortgage that, for various reasons, is considered riskier than a prime mortgage and less risky than a subprime mortgage.

${ }^{20}$ Foreclosure rates for owner-occupied properties and nonlocal investor-owned properties were not found to be statistically significantly different.

${ }^{21}$ Gerardi, Herkenhoff, Ohanian, and Willen (2015) provide numerous references and some comments about the applicability of different types of models.

22 See Mitchell, Malpezzi, and Green (2010) for a more thorough discussion of fair market value.

${ }^{23}$ Mitchell, Malpezzi, and Green (2010) raise the possibility that, in addition to the discount arising from a forced sale, a discount related to one's ethnicity or race might also exist, producing a "double discount."

24 Increased time on the market might also be viewed as a stigma. Time on the market might be a signal that the house is overpriced or has a flaw that has been discovered by other potential buyers. As time passes, sellers lower their reservation price; this produces a lower price and longer time on the market. However, foreclosure status could also reduce the price and the time on the market. Listing price is related to the time a property remains unsold.

25 When discussing own price foreclosure discounts, the corresponding sales price is generally the price received from the REO sale.

${ }^{26}$ Time on the market is an endogenous variable in the price equation.

27 One form of spatial dependence is addressed by a spatial autoregressive model, where the prices of neighboring houses affect the price of the house in question. The other form of spatial dependence is spatially correlated disturbance terms, where the source is the endogenous spatially lagged variable. If the error terms associated with houses $i$ and $j$ are correlated, the price of house $j$, which is the lagged explanatory variable for the price of house $i$, will be correlated with the error term in the equation for the price of house $i$. Spatially correlated disturbance terms can lead to inefficient parameter estimates and, in turn, insignificant $t$-statistics. Meanwhile, if prices of neighboring houses do influence house prices, failing to use a model such as a spatial autoregressive model will result in biased parameter estimates.

28 The references to prior estimates are by Shilling, Benjamin, and Sirmans (1990); Forgey, Rutherford, and VanBuskirk (1994); Hardin and Wolverton (1996); Springer (1996); Carroll, Clauretie, and Neill (1997); and Pennington-Cross (2006). Clauretie and Daneshvary (2009) point out a fundamental problem associated with ordinary least squares (OLS) estimation of the foreclosure effect. While many characteristics of the real estate are controlled for, the condition of the property is often not. This causes the magnitude of the discount to be overestimated because the foreclosure index is inversely related to the condition of the property. Another potential source of bias is whether the valuation of the characteristics is the same for the buyers of the two types of properties.

${ }^{29}$ The existence of negative externalities provides a theoretical justification for public policies and funding to mitigate these adverse effects. This topic is beyond the scope of our article.

30 See Frame (2010) for a detailed review of mortgage foreclosure effects on surrounding property values.

31 The authors use a technique termed "spatial contextual expansion." Simply put, variables of lat, long, lat ${ }^{2}$, long ${ }^{2}$, and lat*long are included in the regression. This allows the impact of the neighborhood and property characteristics to vary across space. If significant, then spatial submarkets within an area appear to exist.

32 For many, but not all cases, "seriously delinquent" is defined as delinquent for 90 or more days. See Geraldi, Rosenblatt, Willen, and Yao (2015) for further details.

33 Their models explicitly measure the effect on home price growth, and they find that such a property experiences a growth rate that is 1 percent less for each foreclosure or seriously delinquent property in excess of the numbers of such properties present when the home was sold the first time. Because the average appreciation from the first 


\section{Cohen, Coughlin, Yao}

to the second sale was 0 percent and most houses had neither a foreclosure nor seriously delinquent property nearby at the time of each sale, the 1 percent reduction in price growth can be roughly interpreted as a 1 percent reduction in the sales price.

\section{REFERENCES}

Anenberg, Elliot and Kung, Edward. "Estimates of the Size and Source of Price Declines Due to Nearby Foreclosures." American Economic Review, August 2014, 104(8), pp. 2527-51; http://dx.doi.org/10.1257/aer.104.8.2527.

Arias, Maria A.; Gascon, Charles S. and Rapach, David E. "Metro Business Cycles." Working Paper No. 2014-046C, Federal Reserve Bank of St. Louis, May 2016; https://research.stlouisfed.org/wp/2014/2014-046.pdf.

Bajari, Patrick; Chu, Chenghuan Sean and Park, Minjung. "An Empirical Model of Subprime Mortgage Default from 2000 to 2007." NBER Working Paper No. 14625, National Bureau of Economic Research, December 2008; http://www.nber.org/papers/w14625.pdf.

Bayer, Patrick; Ferreira, Fernando and Ross, Stephen L. "The Vulnerability of Minority Homeowners in the Housing Boom and Bust." American Economic Journal: Economic Policy, February 2016, 8(1), pp. 1-27.

Been, Vicki. "External Effects of Concentrated Mortgage Foreclosures: Evidence from New York City." Testimony before the Subcommittee on Domestic Policy, Committee on Oversight and Government Reform, U.S. House of Representatives, May 21, 2008; http://www.neighborhoodindicators.org/sites/default/files/publications/testimonybeen.pdf.

Calomiris, Charles W.; Longhofer, Stanley D. and Miles, William R. “The Foreclosure-House Price Nexus: A Panel VAR Model for U.S. States, 1981-2009." Real Estate Economics, Winter 2013, 41(4), pp. 709-46; http://dx.doi.org/10.1111/reec.12011.

Campbell, John Y. and Cocco, João F. "A Model of Mortgage Default." Journal of Finance, August 2015, 70(4), pp. 1495-554.

Campbell, John Y.; Giglio, Stefano and Pathak, Parag. "Forced Sales and House Prices." American Economic Review, August 2011, 101(5), pp. 2108-31; http://dx.doi.org/10.1257/aer.101.5.2108.

Carroll, Thomas M.; Clauretie, Terrence M. and Neill, Helen R. "Effect of Foreclosure Status on Residential Selling Price: Comment." Journal of Real Estate Research, 1997, 13(1), pp. 95-102.

Chan, Sewin; Sharygin, Claudia; Been, Vicki and Haughwout, Andrew. "Pathways After Default: What Happens to Distressed Mortgage Borrowers and Their Homes?" Journal of Real Estate Finance and Economics, 2014, 48(2), pp. 342-79; http://dx.doi.org/10.1007/s11146-012-9400-1.

Cheung, Ron; Cunningham, Chris and Meltzer, Rachel. "Do Homeowners Associations Mitigate or Aggravate Negative Spillovers From Neighboring Homeowner Distress?" Journal of Housing Economics, 2014, 24, pp. 75-88; http://dx.doi.org/10.1016/j.jhe.2013.11.007.

Clauretie, Terrence M. and Daneshvary, Nasser. "Estimating the House Foreclosure Discount Corrected for Spatial Price Interdependence and Endogeneity of Marketing Time." Real Estate Economics, Spring 2009, 37(1), pp. 43-67; http://dx.doi.org/10.1111/j.1540-6229.2009.00234.x.

Clauretie, Terrence M. and Daneshvary, Nasser. "The Optimal Choice for Lenders Facing Defaults: Short Sale, Foreclose, or REO." Journal of Real Estate Finance and Economics, 2011, 42(4), pp. 504-21; http://dx.doi.org/10.1007/s11146-009-9201-3.

Cohen, Jeffrey P; Coughlin, Cletus C. and Lopez, David A. "The Boom and Bust of U.S. Housing Prices from Various Geographic Perspectives." Federal Reserve Bank of St. Louis Review, September/October 2012, 94(5), pp. 341-67; https://research.stlouisfed.org/publications/review/12/09/341-368Cohen.pdf.

Cordell, Larry; Geng, Liang; Goodman, Laurie S. and Yang, Lidan. "The Cost of Foreclosure Delay." Real Estate Economics, Winter 2015, 43(4), pp. 916-56; http://dx.doi.org/10.1111/1540-6229.12107.

Coulson, N. Edward and Zabel, Jeffrey E. "What Can We Learn from Hedonic Models When Housing Markets Are Dominated by Foreclosures?" Annual Review of Resource Economics, June 2013, 5(1), pp. 261-79; http://dx.doi.org/10.1146/annurev-resource-091912-151759. 
Cui, Lin and Walsh, Randall. "Foreclosure, Vacancy and Crime." Journal of Urban Economics, May 2015, 87, pp. 72-84; http://dx.doi.org/10.1016/j.jue.2015.01.001.

Daneshvary, Nasser and Clauretie, Terrence M. "Toxic Neighbors: Foreclosures and Short-Sales Spillover Effects from the Current Housing-Market Crash." Economic Inquiry, January 2012, 50(1), pp. 217-307; http://dx.doi.org/10.1111/j.1465-7295.2011.00380.x.

Davis, Morris A. and Palumbo, Michael G. "The Price of Residential Land in Large US Cities." Journal of Urban Economics, January 2008, 63(1), pp. 352-84; http://dx.doi.org/10.1016/j.jue.2007.02.003.

Deng, Yongheng; Quigley, John M. and Van Order, Robert. "Mortgage Terminations, Heterogeneity and the Exercise of Mortgage Options." Econometrica, March 2000, 68(2), pp. 275-307; http://dx.doi.org/10.1111/1468-0262.00110.

Desai, Chintal A.; Elliehausen, Gregory and Steinbuks, Jevgenijs. "Effects of Bankruptcy Exemptions and Foreclosure Laws on Mortgage Default and Foreclosure Rates." Journal of Real Estate Finance and Economics, October 2013, 47(3), pp. 391-415; http://dx.doi.org/10.1007/s11146-012-9366-z.

Doms, Mark; Furlong, Frederick and Krainer, John. "House Prices and Subprime Mortgage Delinquencies." Federal Reserve Bank of San Francisco Economic Letter, June 8, 2007, No. 14; http://www.frbsf.org/economicresearch/publications/economic-letter/2007/june/house-prices-subprime-mortgage-delinquency/.

Ellen, Ingrid Gould; Lacoe, Johanna and Sharygin, Claudia Ayanna. "Do Foreclosures Cause Crime?" Journal of Urban Economics, March 2013, 74, pp. 59-70; http://dx.doi.org/10.1016/j.jue.2012.09.003.

Favara, Giovanni and Imbs, Jean. "Credit Supply and the Price of Housing." American Economic Review, March 2015, 105(3), pp. 958-92; http://dx.doi.org/10.1257/aer.20121416.

Ferreira, Fernando and Gyourko, Joseph. "A New Look at the U.S. Foreclosure Crisis: Panel Data Evidence of Prime and Subprime Borrowers from 1997 to 2012." NBER Working Paper No. 21261, National Bureau of Economic Research, June 2015; http://www.nber.org/papers/w21261.pdf.

Fisher, Lynn M. and Lambie-Hanson, Lauren. "Are Investors the Bad Guys? Tenure and Neighborhood Stability in Chelsea, Massachusetts." Real Estate Economics, Summer 2012, 40(2), pp. 351-86; http://dx.doi.org/10.1111/j.1540-6229.2011.00317.x.

Fisher, Lynn M.; Lambie-Hanson, Lauren and Willen, Paul S. "The Role of Proximity in Foreclosure Externalities: Evidence from Condominiums." American Economic Journal: Economic Policy, February 2015, 7(1), pp. 119-40; http://dx.doi.org/10.1257/pol.20130102.

Fitzpatrick, Thomas J.; Nelson, Lisa; Richter, Francisca G.-C., and Whitaker, Stephan. "Can Local Housing Ordinances Prevent Neighborhood Destabilization?" Working Paper No. 12-40R, Federal Reserve Bank of Cleveland, October 2014.

Forgey, Fred A; Rutherford, Ronald C. and VanBuskirk, Michael L. "Effect of Foreclosure Status on Residential Selling Price." Journal of Real Estate Research, 1994, 9(3), pp. 313-18.

Foote, Christopher L.; Gerardi, Kristopher S. and Willen, Paul S. "Negative Equity and Foreclosure: Theory and Evidence." Journal of Urban Economics, 2008, 64(2), pp. 234-45; http://dx.doi.org/10.1016/j.jue.2008.07.006.

Foote, Christopher L.; Gerardi, Kristopher S. and Willen, Paul S. "Why Did So Many People Make So Many Ex Post Bad Decisions? The Causes of the Foreclosure Crisis." NBER Working Paper No. 18082, National Bureau of Economic Research, May 2012; http://www.nber.org/papers/w18082.pdf.

Foster, Chester and Van Order, Robert. "An Option-Based Model of Mortgage Default." Housing Finance Review, 1984, 3(4), pp. 351-72.

Foster, Chester and Van Order, Robert. "FHA Terminations: A Prelude to Rational Mortgage Pricing." Journal of the American Real Estate and Urban Economics Association, 1985, 13(3), pp. 273-91; http://dx.doi.org/10.1111/1540-6229.00355.

Frame, Scott W. "Estimating the Effect of Mortgage Foreclosures on Nearby Property Values: A Critical Review of the Literature." Federal Reserve Bank of Atlanta Economic Review, 2010, 95(3); https://www.frbatlanta.org/research/publications/economic-review/2010/vol95no3_effect-of-foreclosures-onproperty-values.aspx. 


\section{Cohen, Coughlin, Yao}

Fuster, Andreas; Zafar, Basit and Cocci, Matthew. "Why Aren't More Renters Becoming Homeowners?" Federal Reserve Bank of New York Liberty Street Economics (blog), September 8, 2014; http://libertystreeteconomics.newyorkfed.org/2014/09/why-arent-more-renters-becominghomeowners.html\#.V1mk2k32Z88.

Gangel, Marshall; Seiler, Michael J. and Collins, Andrew. “Exploring the Foreclosure Contagion Effect Using AgentBased Modeling." Journal of Real Estate Finance and Economics, February 2013, 46(2), pp. 339-54; http://dx.doi.org/10.1007/s11146-011-9324-1.

Garriga, Carlos. "The Recent Boom in House Prices: Why Is this Time Different?" Federal Reserve Bank of St. Louis Economic Synopses, 2013, No. 32, November 22, 2013; https://research.stlouisfed.org/publications/es/13/ES_32_2013-11-22.pdf.

Gerardi, Kristopher; Herkenhoff, Kyle F.; Ohanian, Lee E. and Willen, Paul S. “Can't Pay or Won't Pay? Unemployment, Negative Equity, and Strategic Default." NBER Working Paper No. 21630, National Bureau of Economic Research, October 2015; http://www.nber.org/papers/w21630.pdf.

Gerardi, Kristopher; Lambie-Hansen, Lauren and Willen, Paul S. “Do Borrower Rights Improve Borrower Outcomes? Evidence from the Foreclosure Process." Journal of Urban Economics, January 2013, 73(1), pp. 1-17; http://dx.doi.org/10.1016/j.jue.2012.06.003.

Gerardi, Kristopher and Li, Wenli. "Mortgage Foreclosure Prevention Efforts." Federal Reserve Bank of Atlanta Economic Review, 2010, 95(2); https://www.frbatlanta.org/research/publications/economicreview/2010/vol95no2_foreclosure-prevention-efforts.aspx.

Gerardi, Kristopher; Rosenblatt, Eric; Willen, Paul S. and Yao, Vincent W. "Foreclosure Externalities: New Evidence." Journal of Urban Economics, May 2015, 87, pp. 42-56; http://dx.doi.org/10.1016/j.jue.2015.02.004.

Gerardi, Kristopher; Shapiro, Adam H. and Willen, Paul S. "Subprime Outcomes: Risky Mortgages, Homeownership Experiences, and Foreclosures." Working Paper No. 07-15, Federal Reserve Bank of Boston, May 4, 2008; https://www.bostonfed.org/economic/wp/wp2007/wp0715.pdf.

Goodstein, Ryan M. and Lee, Yan Y. “Do Foreclosures Increase Crime?” Working Paper No. 2010-05, FDIC Center for Financial Research, May 2010.

Goodstein, Ryan M.; Hanouna, Paul; Ramirez, Carlos D. and Stahel, Christof W. "Are Foreclosures Contagious?" Working Paper No. 2011-4, FDIC Center for Financial Research, February 2011; https://www.fdic.gov/bank/analytical/cfr/2011/wp2011/CFR_WP_2011_04.pdf.

Guiso, Luigi; Sapienza, Paola and Zingales, Luigi. "The Determinants of Attitudes toward Strategic Default on Mortgages." Journal of Finance, August 2013, 68(4), pp. 1473-515; http://dx.doi.org/10.1111/jofi.12044.

Hardin, William G. III and Wolverton, Marvin L. "The Relationship between Foreclosure Status and Apartment Price." Journal of Real Estate Research, 1996, 12(1), pp. 101-9.

Harding, John P.; Rosenblatt, Eric and Yao, Vincent W. "The Contagion Effect of Foreclosed Properties." Journal of Urban Economics, November 2009, 66(3), pp. 164-78; http://dx.doi.org/10.1016/j.jue.2009.07.003.

Harding, John P.; Rosenblatt, Eric and Yao, Vincent W. "The Foreclosure Discount: Myth or Reality?" Journal of Urban Economics, March 2012, 71(2), pp. 204-19; http://dx.doi.org/10.1016/j.jue.2011.09.005.

Hartley, Daniel A. "The Effect of Foreclosures on Nearby Housing Prices: Supply or Dis-Amenity?" Regional Science and Urban Economics, November 2014, 49, pp. 108-17; http://dx.doi.org/10.1016/j.regsciurbeco.2014.09.001.

Immergluck, Dan and Smith, Geoff. "The External Costs of Foreclosure: The Impact of Single-Family Mortgage Foreclosures on Property Values." Housing Policy Debate, 2006a, 17(1), pp. 57-79; http://dx.doi.org/10.1080/10511482.2006.9521561.

Immergluck, Dan and Smith, Geoff. "The Impact of Single-Family Mortgage Foreclosures on Neighborhood Crime." Housing Studies, November 2006b, 21(6), pp. 851-66; http://dx.doi.org/10.1080/02673030600917743.

Katz, Charles M.; Wallace, Danielle and Hedberg, E.C. "A Longitudinal Assessment of the Impact of Foreclosure on Neighborhood Crime." Journal of Research in Crime and Delinquency, August 2013, 50(3), pp. 359-89;

http://dx.doi.org/10.1177/0022427811431155. 
Kau, James B. and Keenan, Donald C. "Patterns of Rational Default." Regional Science and Urban Economics, November 1999, 29(6), pp. 765-85; http://dx.doi.org/10.1016/S0166-0462(99)00024-1.

Kau, James B.; Keenan, Donald C. and Kim, Taewon. "Transaction Costs, Suboptimal Termination and Default Probabilities." Journal of the American Real Estate and Urban Economics Association, 1993, 21(3), pp. 247-63; http://dx.doi.org/10.1111/1540-6229.00610.

Leamer, Edward E. "Housing Is the Business Cycle." Proceedings of the 2007 Economic Policy Symposium, "Housing, Housing Finance, and Monetary Policy," Jackson Hole, Wyoming, 2007. Kansas City, MO: Federal Reserve Bank of Kansas City, 2007, pp. 149-233; https://www.kansascityfed.org/publicat/sympos/2007/PDF/Leamer_0415.pdf.

Lee, Kai-yan. "Foreclosure's Price-Depressing Spillover Effects on Local Properties: A Literature Review." Community Affairs Discussion Paper No. 2008-01, Federal Reserve Bank of Boston, September 2008; https://www.bostonfed.org/commdev/pcadp/2008/pcadp0801.pdf.

Leonard, Tammy and Murdoch, James C. "The Neighborhood Effects of Foreclosure." Journal of Geographical Systems, December 2009, 11(4), pp. 317-32; http://dx.doi.org/10.1007/s10109-009-0088-6.

Levitin, Adam J. and Wachter, Susan M. “Explaining the Housing Bubble." Georgetown Law Journal, 2012, 100(4), pp. 1177-258; http://dx.doi.org/10.2139/ssrn.1669401.

Lin, Zhenguo; Rosenblatt, Eric and Yao, Vincent W. "Spillover Effects of Foreclosures on Neighborhood Property Values." Journal of Real Estate Finance and Economics, May 2009, 38(4), pp. 387-407; http://dx.doi.org/10.1007/s11146-007-9093-z.

Mayer, Christopher; Pence, Karen and Sherlund, Shane M. "The Rise in Mortgage Defaults." Journal of Economic Perspectives, Winter 2009, 23(1), pp. 27-50; http://dx.doi.org/10.1257/jep.23.1.27.

Mian, Atif; Amir, Sufa and Trebbi, Francesco. "Foreclosures, House Prices, and the Real Economy." Journal of Finance, December 2015, 70(6), pp. 2587-633; http://dx.doi.org/10.1111/jofi.12310.

Mitchell, Thomas W.; Malpezzi, Stephen and Green, Richard K. “Forced Sale Risk: Class, Race, and the 'Double Discount."' Florida State University Law Review, Spring 2010, 37(3), pp. 589-658.

Molloy, Raven and Zarutskie, Rebecca. "Business Investor Activity in the Single-Family-Housing Market." FEDS Notes, December 5, 2013; https://www.federalreserve.gov/econresdata/notes/feds-notes/2013/business-investoractivity-in-the-single-family-housing-market-20131205.html.

Pennington-Cross, Anthony. "The Value of Foreclosed Property." Journal of Real Estate Research, April-June 2006, 28(2), pp. 193-214.

Price, Russell; Lindsey-Taliefero, Debby; Kelly, Lynne and Brent, William. “Do Pre-Sale and Post-Sale Foreclosure Statutes Impact Foreclosure Starts?" Journal of Financial Risk Management, June 2015, 4(2), pp. 82-91; http://dx.doi.org/10.4236/jfrm.2015.42008.

Rappaport, Jordan. "The Demographic Shift from Single-Family to Multifamily Housing." Federal Reserve Bank of Kansas City Economic Review, Fourth Quarter 2013, pp. 29-58; https://www.kansascityfed.org/publicat/econrev/pdf/13q4Rappaport.pdf.

Rauterkus, Stephanie Y.; Miller, Norman G.; Thrall, Grant I. and Sklarz, Michael A. “Foreclosure Contagion and REO versus Non-REO Sales." International Real Estate Review, Winter 2012, 15(3), pp. 307-24.

Rogers, William H. and Winter, William. "The Impact of Foreclosures on Neighboring Housing Sales." Journal of Real Estate Research, 2009, 31(4), pp. 455-79.

Rosen, Sherwin. "Hedonic Prices and Implicit Markets: Product Differentiation in Pure Competition." Journal of Political Economy, January-February 1974, 82(1), pp. 34-55; http://dx.doi.org/10.1086/260169.

Schuetz, Jenny; Been, Vicki and Ellen, Ingrid Gould. "Neighborhood Effects of Concentrated Mortgage Foreclosures." Journal of Housing Economics, December 2008, 17(4), pp. 306-19; http://dx.doi.org/10.1016/j.jhe.2008.09.004.

Shilling, James D.; Benjamin, John D. and Sirmans, C.F. “Estimating Net Realizable Value for Distressed Real Estate." Journal of Real Estate Research, 1990, 5(1), pp. 129-40.

Siebert, Ralph. "The Impact of Foreclosure on Housing Prices." CESifo Working Paper No. 5196, January 2015; https://www.econstor.eu/bitstream/10419/107373/1/cesifo_wp5196.pdf. 


\section{Cohen, Coughlin, Yao}

Springer, Thomas M. "Single-Family Housing Transactions: Seller Motivations, Price, and Marketing Time." Journal of Real Estate Finance and Economics, November 1996, 13(3), pp. 237-54; http://dx.doi.org/10.1007/BF00217393.

Towe, Charles and Lawley, Chad. "The Contagion Effect of Neighboring Foreclosures." American Economic Journal: Economic Policy, May 2013, 5(2), pp. 313-35; http://dx.doi.org/10.1257/pol.5.2.313.

Turnbull, Geoffrey K. and van der Vlist, Arno J. "Foreclosures, New Construction, and House Prices: Neighborhood Externalities or Supply Effects?" Working Paper No. 1304, University of Central Florida School of Real Estate, September 29, 2014.

Whitaker, Stephan and Fitzpatrick, Thomas J. IV. "Deconstructing Distressed-Property Spillovers: The Effects of Vacant, Tax-Delinquent, and Foreclosed Properties in Housing Submarkets." Journal of Housing Economics, June 2013, 22(2), pp. 79-91; http://dx.doi.org/10.1016/j.jhe.2013.04.001.

Zabel, J. "A Dynamic Model of the Housing Market: The Role of Vacancies." Journal of Real Estate Finance and Economics, May 2014, online article; http://dx.doi.org/10.1007/s11146-014-9466-z. 